Discussion

Papers

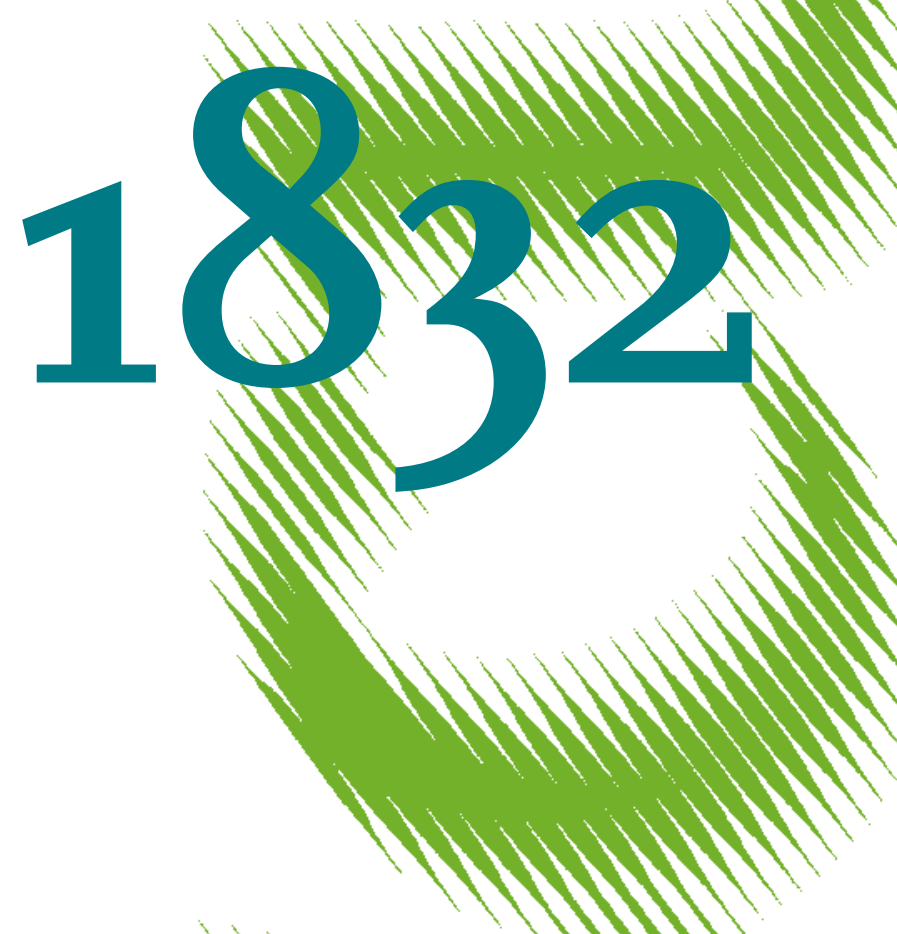

Rent Control, Market Segmentation, and Misallocation: Causal Evidence from a Large-Scale Policy Intervention 
Opinions expressed in this paper are those of the author(s) and do not necessarily reflect views of the institute.

IMPRESSUM

(C) DIW Berlin, 2019

DIW Berlin

German Institute for Economic Research

Mohrenstr. 58

10117 Berlin

Tel. +49 (30) $89789-0$

Fax +49 (30) $89789-200$

http://www.diw.de

ISSN electronic edition 1619-4535

Papers can be downloaded free of charge from the DIW Berlin website:

http://www.diw.de/discussionpapers

Discussion Papers of DIW Berlin are indexed in RePEc and SSRN:

http://ideas.repec.org/s/diw/diwwpp.html

http://www.ssrn.com/link/DIW-Berlin-German-Inst-Econ-Res.html 


\title{
Rent Control, Market Segmentation, and Misallocation: Causal Evidence from a Large-Scale Policy Intervention*
}

\author{
Andreas Mense $^{\mathrm{a}}$, Claus Michelsen ${ }^{\mathrm{b}}$, Konstantin A. Kholodilin ${ }^{\mathrm{b}}$ \\ ${ }^{a}$ School of Business and Economics, University of Erlangen-Nuremberg, Findelgasse 7, 90402 \\ Nuremberg, Germany \\ ${ }^{b}$ DIW Berlin, Mohrenstraße 58, 10117 Berlin, Germany
}

\begin{abstract}
This paper studies market segmentation that arises from the introduction of a price ceiling in the market for rental housing. When part of the market faces rent control, theory predicts an increase of free-market rents, a consequence of misallocation of households to housing units. We study a large-scale policy intervention in the German housing market in 2015 to document this mechanism empirically. To identify the effect we rely on temporal variation in treatment dates, combined with a difference-in-differences setup and a discontinuity-intime design. By taking a short-run perspective, we are able to isolate the misallocation mechanism from other types of spillovers. We find a robust positive effect on free-market rents in response to the introduction of rent control. Further, we document that rent control reduced the propensity to move house within rent controlled areas, but only among highincome households. Interpreted through the lens of our theoretical model, this spillover is a clear sign of misallocation. Further, we document that the spillover brings forward demolitions of old, ramshackle buildings.
\end{abstract}

Keywords: Misallocation; price ceilings; rent control; spillovers.

JEL classification: D2; D4; R31.

${ }^{*}$ We thank seminar participants at the Spatial Dimensions of Inequality Workshop at ZEW Mannheim, the Economic Geography Workshop at the University of Jena, the V Workshop on Urban Economics at IEB, the SERC workshop at LSE, the annual meetings of Verein für Socialpolitik 2017, Urban Economics Association 2017, Royal Economic Society 2018, European Urban Economics Association 2018, AEA at ASSA 2019, and the ESCP-TAU-UCLA Housing Conference Madrid 2019. We are grateful for valuable comments and suggestions from Gabriel Ahlfeldt, Guillaume Chapelle, Jeffrey Cohen, Paul Cheshire, Richard Green, Christian Hilber, Mathias Hoffmann, Tim McQuade, Henry Overman, Christopher Palmer, Gary Painter, Johannes Rincke, Andrés RodríguezPose, Tuukka Saarimaa, Kurt Schmidheiny, Olmo Silva, Nitzan Tzur, and Matthias Wrede. An earlier version of this paper circulated under the name Empirics on the Causal Effects of Rent Control in Germany. 


\section{Introduction}

Regulators frequently intervene in the price mechanism of markets, for example in form of minimum wages, or price controls for fuels, agricultural products, and pharmaceuticals. Likewise, housing markets are many times subject to price regulations (see Figure 1), frequently accompanied by long-standing, emotional debates amongst scholars and policy makers, centered on distributional issues. If not at the national level, then rent controls often exist at the local level, e.g. in the United States and France. Nearly every textbook on housing and real estate economics covers this topic (see, e.g. McDonald and McMillen, 2010; O'Sullivan and Irwin, 2007). Affordable housing is also a major topic in election campaigns. For example, in 1948, U.S. President Harry S. Truman won the White House by campaigning for the Fair Deal, which included a promise to resolve housing shortages (Von Hoffman, 2000). Even in recent years, affordable housing remains a vibrantly discussed topic: In light of sharply increasing rents in urban areas in Germany, the Social Democrats succeeded in launching a debate around the need for stricter rent controls in the 2013 German Bundestag elections (Knaup et al., 2013). In the UK, increases in rents and rising shares of privately owned rental housing fuel the ongoing debate on rent control (Wilson, 2017), and housing played a major role in the 2015 UK general elections (Kelly, 2015). Inspired by the German rent control regime, Lille and Paris (France) introduced similar regulations in 2014 and $2015 .^{1}$

In this paper, we study market segmentation that arises from the introduction of a price ceiling in the market for rental housing in Germany in 2015. This policy intervention can be considered to be a poster-child of so-called "second-generation rent control". ${ }^{2}$ This regulation establishes a rent ceiling only for a part of the market, leaving the price mechanism in the rest intact. Because the artificially lowered rents

\footnotetext{
${ }^{1}$ The Paris ordinance was repealed by court in 2017.

${ }^{2}$ There are various types of rent controls that differ in their rules, scope and restrictiveness. A simple taxonomy distinguishes between first- and second-generation rent controls (Turner and Malpezzi, 2003; Arnott, 1995): First-generation rent controls target the entire market, while secondgeneration controls, implemented since the mid 1960s, regulate only parts of the market. Supporters of rent controls further argue that second-generation regulations, if adequately designed, can increase welfare, e.g. by stimulating additional construction activity in the uncontrolled part of the housing market (Arnott, 1995; Skak and Bloze, 2013).
} 
enlarge the pool of potential renters of rent controlled units, the rent ceiling crowds out some households whose willingness to pay exceeds by far the rent ceiling. These households bid up rents in the free market. To the best of our knowledge, this paper provides first quasi-experimental evidence for this mechanism which can be associated to misallocation of households to housing units.

In contrast to other rent control policies studied previously, the German rent cap is a pure price control. It did not impose other constraints on landlords that could also influence landlord or renter behavior. This puts us in the unique position to study the important theoretical mechanism triggered by the introduction of a price cap. As such, the German rent control policy represents an excellent test-case to empirically evaluate the causal effects of rent control on regulated and free-market rents, and hence misallocation.

Figure 1: National rent controls around the world (2017)

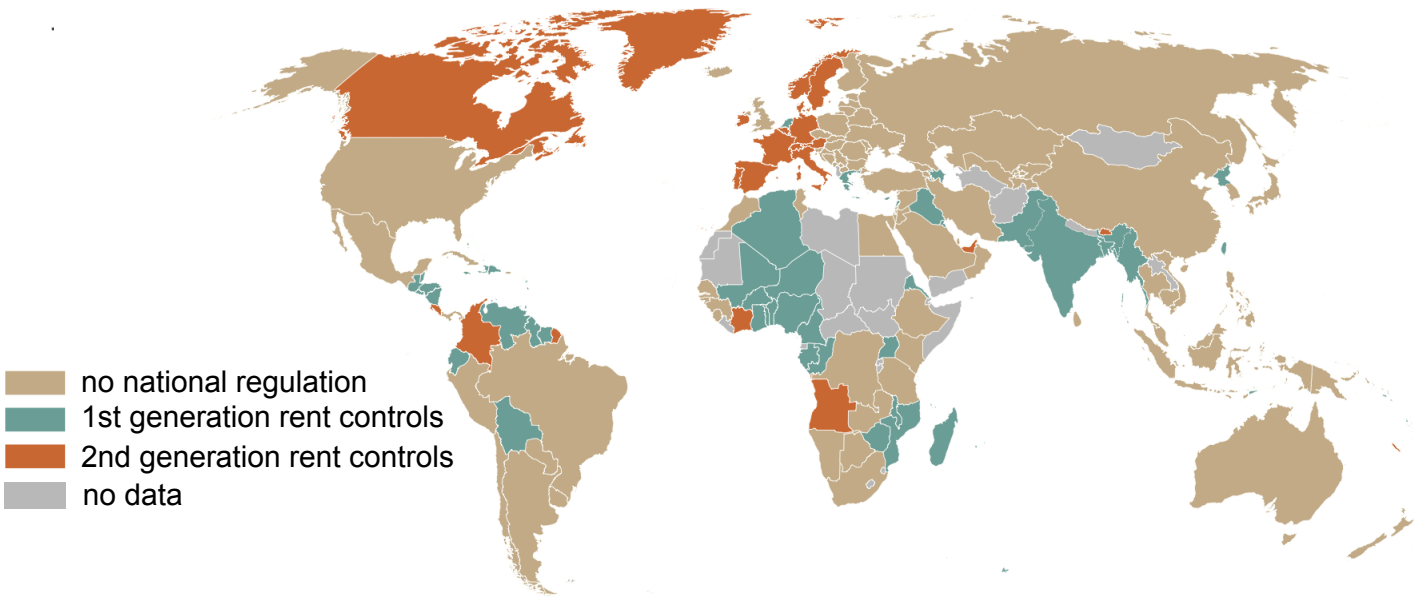

Source: Kholodilin et al. (2018); Many countries have implemented rent controls or used to have regulations for rental housing at the national level. Others do not have national rules but substantial regulations on the local level, e.g. the United States.

For many reasons, economists oppose such regulations. Because price caps distort the price signal, they are expected to reduce investment in rental housing. ${ }^{3}$ Impor-

\footnotetext{
${ }^{3}$ The extensive literature on rent controls almost unanimously opposes regulations - even the more flexible forms - finding them to be inefficient instruments at fighting the effects of housing market shortages (Arnott, 1995; Glaeser and Luttmer, 2003). Available studies suggest that rent
} 
tantly, they are also expected to cause misallocation (Glaeser and Luttmer, 2003).

This paper picks up two important aspects from the economic debate revolving around price controls in general and the effects of rent controls specifically: First, based on an excellent housing market example, we provide quasi-experimental evidence on the distorting effects of price controls on the allocation of goods.(Glaeser and Luttmer, 2003; Davis and Kilian, 2011; Wang, 2011). We demonstrate theoretically and empirically, that market segmentation — induced by price regulation - causes substantial misallocation. Particularly in housing market context, quasi-experimental evidence for misallocation is scarce; both Glaeser and Luttmer (2003) and Skak and Bloze (2013) exploit cross-sectional variation in rent control. Glaeser and Luttmer (2003) argue that traditional welfare analysis often ignores welfare losses from misallocation, i.e. from the allocation of goods to buyers who do not value these goods the most. So far, the literature on price controls focuses mainly on quantity responses, e.g. in the labor market in response to minimum wages (Card and Krueger, 1994; Stewart, 2004; Dube et al., 2010, 2016), a point noted already by Glaeser and Luttmer (2003).

Second, we provide evidence to the small, but growing literature that analyzes the causal effects of rent controls. In a recent working paper, Diamond et al. (2017) finds that tenancy rent control reduces household mobility, the size of the rental housing stock, and leads to city-wide increases of rents. Results from Sims (2007) and Autor et al. (2014) point in the direction that there is only a small effect of rent control on construction activity, but a shift of dwellings from rental to owner-occupied status and a deterioration in the quality of existing rental units (Sims, 2007), while the impact

controls cause immediate reductions to the market value of rental housing (Early and Phelps, 1999; Fallis and Smith, 1985; Marks, 1984), depress refurbishment, reduce maintenance (Kutty, 1996; Andersen, 1998; Olsen, 1988b; Moon and Stotsky, 1993), slow construction activity (McFarlane, 2003; Glaeser and Luttmer, 2003), and induce inefficient allocation of units (Glaeser and Luttmer, 2003; Arnott and Igarashi, 2000), while - in the short run - having ambiguous effects on rents (Nagy, 1997; Early, 2000; Fallis and Smith, 1984; Smith, 1988). Furthermore, the targeted groups only partially benefit (Linneman, 1987; Ault and Saba, 1990; Glaeser, 2003). Most of these results are derived from theoretical models that - depending on the viability of the assumptions - provide, at best, ambiguous predictions on the effects of rent controls, as some authors criticize in this context (Arnott, 1995; Olsen, 1988a,b; Kutty, 1996). 
on the price of the non-controlled housing stock is substantial (Autor et al., 2014). ${ }^{4}$ These two latter studies analyze the end of rent control in Cambridge, Massachusetts, USA, in 1995. As noted above, spillovers from the regulated part of the market to other parts work through various channels, including maintenance, household sorting, and the consequences thereof. The spillovers documented in Sims (2007) and Autor et al. (2014) are positive, suggesting that the maintenance and household sorting channels dominate in the long-run (Cambridge rent control lasted for 25 years). In contrast to these papers, we isolate an opposite-sign spillover effect that is due to misallocation. The short-run perspective makes it less likely that these more inert channels influence the results. It also allows us to abstract from the impacts of a potential, negative response of the supply of rental housing (as in Diamond et al., 2017). Moreover, the paper provides first evidence on the effects of rent control in a European housing market with a high share of rental housing.

Our results are important for the following reasons. First, price controls are ubiquitous in housing and labor markets. In both cases, they typically only apply to part of the market. We provide clean evidence on the misallocation mechanism that is triggered by such market interventions. For instance, minimum wage regimes typically do not restrict self-employed persons, giving rise to the same misallocation mechanism that we uncover for the case of second-generation rent controls. Second, we extend the analysis in Glaeser and Luttmer (2003) to partly controlled markets and provide a much simpler test of misallocation that relies exclusively on the price reaction. This is important for settings where other buyer and goods characteristics are unobservable. Whereas our test could be easily applied to minimum wages if the researcher observes only the wage rates in the two market segments, the approach suggested by Glaeser and Luttmer (2003) requires data on job and worker characteristics. Third, although we cannot determine the long-run welfare costs (or benefits) of the policy, it is important to understand the individual mechanisms triggered by a policy - both for the design of adequate models and for the design of future housing market policies.

\footnotetext{
${ }^{4}$ Relatedly, Autor et al. (2017) use rent de-control to show that gentrification reduces (or crowds out) crime.
} 
We exploit the spatial, temporal, and within market variation generated by the law and combine a difference-in-differences strategy with a discontinuity in time design that identifies sharp drops (or hikes) in the continuous trend of rents (see Hausman and Rapson, 2017). Additional identifying variation comes from the different start dates across the eleven federal states that adopted the regulation. In the analysis, we focus on three aspects: first, we analyze the impact of the rent cap on regulated and unregulated rents within a housing market. We focus on the short run effects and find that regulated rents decreased immediately after the rent cap became effective, while rents in the free-market segment increased after a lag of one to two months. Second, we focus on the supply side effects of the rent cap. We do not find evidence for negative short-run impacts on housing quality through reduced refurbishment and maintenance efforts. In a previous study (Mense et al., 2019), we find evidence that prices for building lots increased in regulated markets, which is consistent with positive revenue expectations for new (unregulated) residential buildings. Our analysis further reveals that a larger number of small residential buildings were demolished in 2016 in order to be replaced with a new residential building, suggesting positive (long-run) effects on total housing supply. However, the numbers of completed dwelling units did not significantly differ in 2016 or 2017. Finally, we assess the demand responses to the regulation and analyze to what extent households of different income groups benefit from the rent cap. We use data from the German Socio-Economic Panel and estimate the probability that a household rents a new dwelling within a regulated region. The results show that the regulation significantly decreased the likelihood for high-income households - compared to middle- and low-income groups - to move within regulated areas.

Our empirical findings fit exceptionally well the predictions of a standard comparative-static model of a divided (controlled/free) housing market (see, e.g. McDonald and McMillen, 2010; Skak and Bloze, 2013). We formalize and generalize the graphical model to show that an increase in free-market rents in response to rent control is a clear sign of misallocation of households to housing units. Furthermore, the size of the welfare loss related to misallocation increases with the strength of the spillover. The mechanism is as follows: Rent control allows some households, which otherwise 
would have been unwilling to rent a unit in the market, to compete for rent-controlled units, thereby replacing other households with higher willingness to pay. The latter households move to the free-market segment and bid up the price there. In contrast to our findings, previous empirical studies focusing on spillover effects find a decrease in free-market prices in response to rent control (Sims, 2007; Autor et al., 2014). In fact, Autor et al. (2014) propose two alternative channels that may give rise to these same-sign spillovers: externalities through (i) higher maintenance and (ii) spatial sorting by income. We argue that these alternative channels are closed in the short run, thus allowing us to identify the opposite-sign spillover.

The remainder of this paper is structured as follows: In the next section, we present a simple theoretical framework that helps to interpret the effect of rent control on free-market rents. Then, we outline the institutional background and stylized facts regarding recent developments in the German housing market in Section 3. In Section 4, we present our empirical strategy and the results. In the final section, we discuss our findings.

\section{The effects of rent controls on rents in regulated and unregulated mar- kets}

The standard prediction of a comparative-static model of the housing market is that a cap on rents reduces revenues for landlords, house prices, and incentives to invest. In the long-run, the housing stock declines. As some authors argue, this result is not straight-forward for second-generation rent controls (Arnott, 1995; Olsen, 1988a,b; Kutty, 1996). In particular, settings that divide the market into a regulated and a free segment (e.g., dwellings built before/after a specific date) can generate a positive effect on free-market rents, representing an incentive to invest. This section establishes that this positive effect on free-market rents is induced by misallocation and can hence be used as the basis for an empirical test of misallocation.

\subsection{A comparative static representation of second-generation rent controls}

Housing is immobile and durable - naturally, there exist different regional market equilibria. Moreover, housing markets are spatially and qualitatively segmented (see, 
e.g., Goodman and Thibodeau, 1998). These market segments are typically interconnected: for example, if demand and thus rents in city centers rise, households substitute rental payments for commuting costs and move to the periphery of the market. On the one hand, the interconnectedness of the markets is ideal to find counterfactuals for market developments in regulated and unregulated areas. On the other hand, the free segments of the market are also affected by the regulation of a specific sub-segment.

This effect can be illustrated in a standard comparative-static framework (see, for example McDonald and McMillen, 2010; Skak and Bloze, 2013), as depicted in Figure 2: consider an unregulated market where demand $(D)$ for housing decreases with the rent level (vertical axis). At the intersection with the perfectly inelastic short-run housing supply $\left(S_{s}\right)$, the market is in equilibrium, providing $h_{s}$ units of housing services (a function of housing quantity and quality). Ideally, the short-run equilibrium is identical with the long-run balance of demand and supply $\left(S_{l}\right)$. The slope of the long-run supply curve is determined by the costs of new development, maintenance, and refurbishment. The housing stock expands as long as rental income exceeds costs of housing service production. If rents are limited to a level below the market equilibrium, refurbishment effort is reduced and the deterioration exceeds new housing supply (for a detailed discussion, see, Arnott et al., 1983). Here, we abstract from such supply effects in order to focus the discussion.

Now consider the introduction of rent control. Under first-generation rent control, the controlled price applies to the whole market (Figure 2a). As for some units, marginal costs of renting out the unit exceed the controlled price, supply declines to $S_{c}$, implying a loss of (rental) housing units equal to $h_{s}-h_{c}$. The controlled price allows households that would have been forced to leave the market in absence of rent control to compete for dwellings in the city. Dwellings are allocated to households by mechanisms other than willingness to pay, e.g. queuing, lottery, or nepotism. Under random allocation, the welfare loss resulting from misallocation is equal to the red tetragon (see Glaeser and Luttmer, 2003).

In second-generation rent control, the controlled price applies only to part of the market (Figure 2b). This divides the housing stock $h_{s}$ into a regulated segment $\left(h_{c}\right)$ 
Figure 2: Misallocation under first- and second-generation rent controls

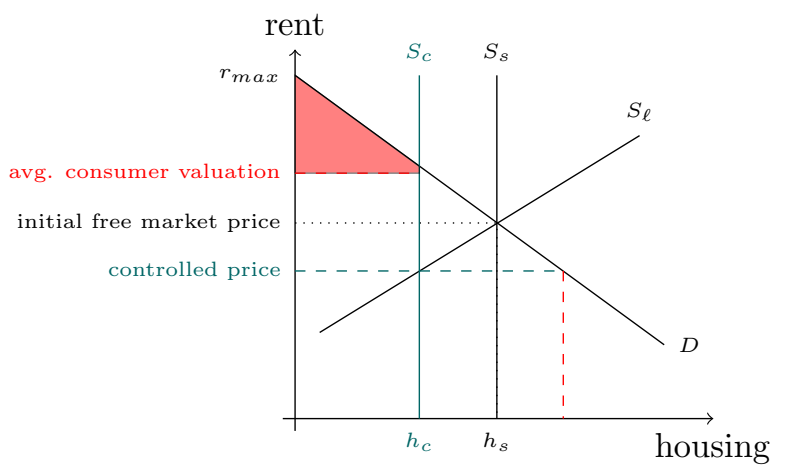

a. First-generation rent control

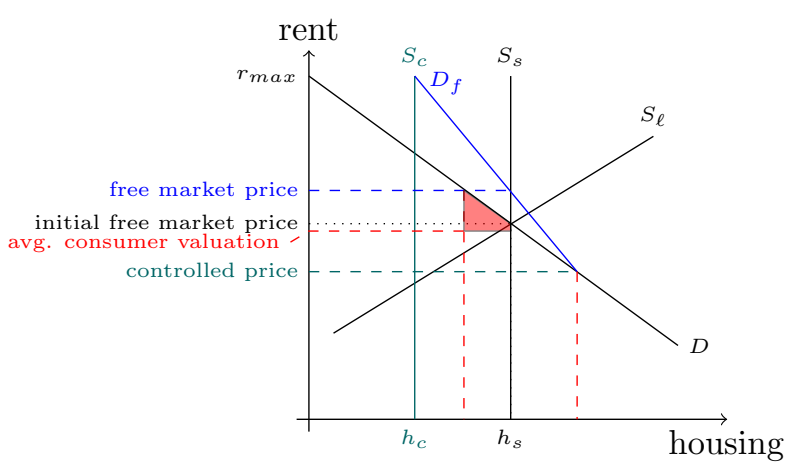

b. Second-generation rent control

and a free-market segment $\left(h_{s}-h_{c}\right)$. In the free-market segment, housing units are allocated by willingness to pay. Let us assume that allocation in the regulated segment is random. This implies that households unable to benefit from rent control are a random subset of all households whose willingness to pay exceeds the controlled price. Thus, the demand curve in the free-market segment, $D_{f}$, connects the intersection of $S_{c}$ and the maximum willingness to pay $r_{\max }$ with the intersection of the controlled price and $D_{f}$. In this setting, the introduction of the rent cap pushes up the price of new dwellings from the initial to the new free-market price. The driving force behind this result is the random allocation of households to rent controlled units. ${ }^{5}$

\footnotetext{
${ }^{5}$ An alternative explanation for increased prices of uncontrolled units could be a reduction of supply of controlled units, by conversion to owner-occupied status. Then, it would be possible to observe a positive spillover to free market rents even if there is no misallocation: The reduced supply
} 
The welfare loss due to misallocation is depicted by the red tetragon. The relevant part of the demand curve lies between the two vertical dashed red lines; these households have a willingness to pay that is below the price in the free-market segment, but above the controlled price. Because these households are allocated randomly to rent-controlled units, what matters for welfare is the average consumer valuation in this group (depicted by the horizontal dashed red line).

The simple graphical representation has several interesting implications: As the introduction of rent control leads to a decline of rents in the controlled sector, this triggers an increase of free-market rents. Since house prices are determined by future rental income, prices of building lots where new, unregulated housing can be developed should also increase. Finally, if land supply is elastic, there should be positive effects on new construction. The previous literature shows that negative impacts on housing supply as well as neighborhood sorting are also likely. However, these latter effects likely need more time to unravel. Thus, we can isolate the misallocation-induced rent spillover by taking a short-run perspective.

\subsection{A simple formal model}

To generalize the previous discussion and to derive more precise propositions, we develop a simple formal model. The model shows that, under partial price control, there is misallocation if at least some households with willingness to pay for a dwelling below the initial equilibrium price get to consume at the controlled price. This outcome is associated with an opposite-sign spillover to the free-market price.

Baseline. Assume households living in a dwelling receive utility $u=\varepsilon-r$, where $\varepsilon$ has distribution $F, F^{-1}$ exists, and $r$ is the rent. The supply of housing units is costless and fixed at quantity 1 and there are $N>1$ potential renters. Through competition, households bid up rents, and the marginal renter determines the equilibrium rent level. Households that do not get to rent a unit receive utility 0 from living somewhere else.

would lead to a movement up the original demand curve. Arguably, this type of spillover is very small, unless a substantial share of the rental housing stock is converted, which we deem highly unlikely in the short run. 
It must hold that

$$
1=N\left(1-F\left(\varepsilon_{0}\right)\right)
$$

where $\varepsilon_{0}$ is the willingness to pay of the marginal renter. Letting $r_{0}$ denote the equilibrium rent level prior to rent control, we have

$$
r_{0}=F^{-1}\left(1-\frac{1}{N}\right)
$$

Rent control. Suppose that rent control is introduced for a share $0<\rho \leq 1$ of units. These units must not be rented out at a price higher than $\bar{r}<r_{0}$. Letting $J \subseteq[\bar{r}, \infty)$ denote households that get to rent one of these units, the equilibrium conditions are

$$
\begin{aligned}
\rho & =N \int_{J} d F(\varepsilon), \\
1-\rho & =N \int_{K} d F(\varepsilon)
\end{aligned}
$$

where $K \subseteq\left[r_{0}, \infty\right) \backslash J$. For given $\rho$ and $J$, this determines the free market rent $r_{1}$,

$$
r_{1}=\inf K
$$

In the polar case where $J=\left[F^{-1}(1-\rho / N), \infty\right)$, households with the highest willingness to pay get to live in rent controlled units. Hence,only households with willingness to pay below $F^{-1}(1-\rho / N)$ compete on the free market. Note that, because units are allocated to the highest bidders on the free market, $K=\left[r_{1}, F^{-1}(1-\rho / N)\right.$ ) must hold for some $r_{1}$ (i.e., $K$ must not have any holes). In this case, the price on the free market does not change upon imposition of rent control:

$$
\begin{gathered}
J=\left[F^{-1}\left(1-\frac{\rho}{N}\right), \infty\right) \Rightarrow 1-\rho=N \int_{\left[r_{1}, F^{-1}(1-\rho / N)\right)} d F(\varepsilon) \\
\Rightarrow \frac{1-\rho}{N}=1-\frac{\rho}{N}-F\left(r_{1}\right) \Rightarrow F\left(r_{1}\right)=1-\frac{1}{N} \Rightarrow r_{1}=r_{0} .
\end{gathered}
$$

Hence, there is no spillover to free market rents in this case.

Now, we consider the general case. Let $B$ be a set of households with willingness 
to pay above $F^{-1}(1-\rho / N)$, i.e. $B \subseteq\left[F^{-1}(1-\rho / N), \infty\right)$. Clearly, $N F(B) \leq \rho$. Let $X=\left[r_{0}, F^{-1}(1-\rho / N)\right)$ and let $A$ be a set that satisfies $A \subseteq\left[\bar{r}, F^{-1}(1-\rho / N)\right)$ and $F(A)=F(B)$. Households in $A$ get to live in a rent controlled unit, replacing households from $B$. Formally, the set of renters in the controlled segment is $A \cup$ $\left[F^{-1}(1-\rho / N), \infty\right) \backslash B$.

Define $C:=A \cap X$ and $D:=A \backslash X$ as the subsets of $A$ that are above and below the initial market price $r_{0}$. There are two relevant cases, $F(D)>0$ and $F(D)=0$.

First, consider the case $F(D)=0$. There is no household with willingness to pay below $r_{0}$ that replaces a household with willingness above $r_{0}$ under rent control. Clearly, there is no welfare loss from misallocation in this case, but there is redistribution from landlords of rent controlled units to their renters, and from renters of free market units to their landlords. $F(D)=0$ implies $F(C)=F(A)=F(B)$, so that

$$
1-\rho=F(X \backslash C)+F(C)=F(X \backslash C)+F(B) .
$$

This means that

$$
r_{1}=\inf X \backslash C= \begin{cases}r^{*}>r_{0} & \text { if } \exists \delta>r_{0} \text { s.t. }\left[r_{0}, \delta\right) \subseteq C \\ r_{0} & \text { otherwise. }\end{cases}
$$

The first case is not relevant in practice, because it implies that virtually all renters below $\delta$ get to live in a rent controlled unit. Furthermore, the spillover would likely be small, as there is no good reason why all households with willingness to pay above $r_{0}$ and below $r^{*}$ would end up in the rent-control segment of the market for larger $r^{*}$, while at the same time, there are other regions in $X$ where no household lives in a rent-controlled unit, althouth their willingness to pay exceeds $r^{*}$. Hence, empirically, we would expect that $r_{1}=r_{0}$ under no misallocation.

Now let $F(D)>0$. Since $F(D)+F(C)=F(A)=F(B)$, we have

$$
\frac{1-\rho}{N}=F(X)=F(X \backslash C)+F(C)<F(X \backslash C)+F(B) .
$$

Hence, it follows that $r_{1}>\inf X \backslash C \geq \inf X=r_{0}$. The strict inequality follows from the fact that competition on the free market ensures an allocation of dwellings to the 
highest bidders in $X \backslash C$, while there are not enough dwellings on the free market to accommodate all households in $X \backslash C$. In other words, if there are households without a dwelling whose willingness to pay exceeds $r_{0}$, rent control pushes up rents in the free segment of the market.

The welfare loss due to misallocation is

$$
\Delta=N\left(\int_{E} \varepsilon d F-\int_{D} \varepsilon d F\right),
$$

where $E=\left[r_{0}, r_{1}\right) \backslash C$, and it must hold that $F(E)=F(D)$. Households in $D$ benefit since they received utility 0 prior to rent control but pay $\bar{r}$ under rent control to get utility $v>\bar{r}$. On the other hand, households in $E$ had net utility $v-r_{0}>0$ prior to rent control, but get 0 afterwards. Other renters gain or lose as well, but these gains and losses are matched by equally sized losses and gains of landlords. Clearly, $\Delta<0$, because $\sup D \leq \inf E$ and $\inf D<\sup E$.

For given $r_{0}, \bar{r}$, it is clear that $\int_{E} \varepsilon d F$ weakly increases with $r_{1}$, while $\int_{D} \varepsilon d F$ is constant. This implies that the welfare loss weakly increases in $r_{1}$.

These results give rise to the following proposition:

Proposition. Consider the simple model described above.

(i) A test of the null hypothesis $r_{1}=r_{0}$ is a test of no misallocation.

(ii) For a given initial equilibrium price $r_{0}$ and a rent ceiling $\bar{r}$, the welfare loss due to misallocation weakly increases in $r_{1}$.

\section{The German housing market: stylized facts and institutional setting}

Before outlining our empirical strategy in detail, we briefly introduce key figures about the German housing market, discuss the institutional setting with the specific mechanisms of the "Mietpreisbremse," and how this setting generates variation in the data that allows us to identify the causal effects of rent control on free-market prices.

\subsection{The German rental housing market}

The German housing market is characterized by a relatively low homeownership rate: approximately $45 \%$ of all dwellings are owner-occupied. According to official 
data (Federal Statistical Office, 2013), housing expenses - including rental payments, heating, and maintenance - of German households account for approximately $34 \%$ of their total expenditures. The net rent (27\% of all expenses) is the largest component of private consumption, the next being transportation at just $14 \%$. Thus, frictions on the housing market have immediate impact on the well-being of a large proportion of the German population, especially in urban areas.

Figure 3: Rents and vacancy rates in Germany


Source: *Federal Statistical Office (Statistisches Bundesamt), Statistical Office for BerlinBrandenburg (Amt für Statistik Berlin-Brandenburg); calculations by the authors; Index 2010=100; **empirica ag.

Between 1995 and 2010, the German housing market was relaxed. Low birth rates, outmigration from city centers to the periphery, and high construction activity in the 1990s contributed to this development. However, since 2010, urban agglomerations have become more attractive. Thanks to an inflow of migrants from smaller cities and from abroad, the population of large German cities began to expand quickly. The result was a housing shortage, particularly putting pressure on rents for new contracts (see Figure 3).

After 15 years of stagnation, rents started to increase rapidly, while vacancy rates fell, particularly in the urban housing stock. In 2016, rents were on average $23 \%$ above the level observed in 2010, in urban areas about 27\%. However, according to the Federal Statistical Office, tenant mobility is quite low: the length of a rental contract exceeds 10 years on average. Therefore, rents across all contracts (new and current) increased only slightly (see Figure 3) since 2010. 


\subsection{The rent cap for new contracts}

Rent controls in Germany have a long history. First introduced in the early 1920s, many regulations, often rudimentary, were in place for decades. Particularly in times of extremely tight housing markets, regulation of rental housing was a preferred policy option. So-called second-generation rent controls were initially implemented in 1972 .

Table 1: rent cap ordinances by federal states

\begin{tabular}{lllrr}
\hline Federal state & Ordinance & Validty period & Regulated/all & Cumulative \\
\hline Berlin & MietenbegrenzungsVO & $2015 / 06-2020 / 05$ & $1 / 1$ & 1 \\
Hamburg & MietpreisbegrenzungsVO & $2015 / 07-2020 / 06$ & $1 / 1$ & 2 \\
North Rhine-Westphalia & MietpreisbegrenzungsVO & $2015 / 07-2020 / 06$ & $22 / 396$ & 24 \\
Bavaria & MietpreisbremseVO & $2015 / 08-2020 / 07$ & $144 / 2056$ & 168 \\
Baden-Württemberg & MietpreisbegrenzungsVO & $2015 / 10-2020 / 09$ & $68 / 1101$ & 236 \\
Rhineland Palatinate & MietpreisbegrenzungsVO & $2015 / 10-2020 / 10$ & $3 / 2306$ & 239 \\
Hesse & MietenbegrenzungsVO & $2015 / 11-2019 / 06$ & $16 / 426$ & 255 \\
Bremen & Mietenbegrenzungs-VO & $2015 / 12-2020 / 11$ & $1 / 2$ & 256 \\
Schleswig-Holstein & MietpreisVO & $2015 / 12-2020 / 11$ & $12 / 1116$ & 268 \\
Bavaria & MieterschutzVO & $2016 / 01-2020 / 07$ & $137 / 2056$ & 261 \\
Brandenburg & MietpreisbegrenzungsVO & $2016 / 01-2020 / 12$ & $31 / 419$ & 292 \\
Thuringia & MietpreisbegrenzungsVO $^{a} 2016 / 04-2021 / 01$ & $2 / 913$ & 294 \\
\hline 16 municipalities listed in the Bavarian MietpreisbremseVO were removed, while nine new municipalities were
\end{tabular}

The most recent regulation was introduced in 2015: the German parliament passed a law that empowered state governments to introduce a rent cap in municipalities characterized by "tight housing markets." This rent cap introduces a rent ceiling for new rental contracts that depends on past local rent growth. For a maximum of five years, a municipality, or part of it, can be declared as a tight housing market if at least one of the following four criteria is met: (1) local rents grow faster than at the national average; (2) the local average rent-to-income ratio is significantly higher than the national average; (3) the population is growing while new housing construction does not create enough dwellings; or (4) the vacancy rate is low, while demand is high. In new contracts, rents are not allowed to exceed the typical local rent by more than $10 \%{ }^{6}$

\footnotetext{
${ }^{6}$ The local reference rent is documented in so-called Mietspiegel, that is, a survey of rents in the municipality, which should be updated at least every two years. If a Mietspiegel does not exist, the local reference rent can also be determined by a sworn expert on a by-case basis or by taking the average rent for at least three comparable housing units. Mietspiegel are considered to be the most
} 
There are four major exceptions from the law: First, rents are freely negotiable for contracts of newly built dwellings (housing completed after October 1, 2014) and all contracts that follow. Second, units that are rented out temporarily are exempted. Third, there is no limit on the rent in the first contract after a substantial refurbishment of an existing dwelling (worth at least one-third of today's reconstruction costs of the dwelling). Fourth, if the rent of the previous contract was above the limit of the rent cap, landlords may conclude this level in all subsequent contracts. Eleven

Figure 4: Population subject to rent regulation



federal states implemented the rent cap at the local level between June 2015 and April 2016 - at various points in time (see Table 1). Two years after their introduction, the rent cap was adopted in 294 municipalities. These municipalities have a population of about 21.5 million inhabitants, and represent one-fourth of the German housing stock (see Figure 4). The regulation concentrates on urban areas, where rent and house price increases have gained strong momentum since 2010 (see section 3.1).

However, law enforcement is quite weak. Since rent control falls under civil law, there are no direct consequences for non-compliant landlords, as it is not possible to impose fees or other juducial measures. If a tenant sucessfully litigates a case, landlords have to refund the overpaid rent and bear all legal costs. Meanwhile, a

objective and affordable way of determining the local reference rent and, from a legal standpoint, they are given precedence over other ways to calculate the typical local rent. However, apart from many methodological drawbacks (for a detailed discussion, see, Lerbs and Sebastian, 2015), the major pitfall is that Mietspiegel are not available for many smaller municipalities subject to the rent cap. 
well-organized and efficient legal industry that asserts the interests of tenants has been established.

Because the rent cap is based on a moving average of rents, the short run effects of the rent regulation depend on the dynamics prior to the introduction. Given the short run rigidity of housing supply, an exponential growth model for rents seems plausible for describing the rent dynamics over a limited window around the introduction of a new regulation. This model is essentially the basis of a log-linear regression of rents on a time trend. Let

$$
R_{t}=a e^{\gamma t}, \quad t \in \mathbb{N}_{0}, \quad a>0
$$

where $R_{t}$ is the rent level at $t, \gamma$ is the constant growth rate, and $a$ is a catch-all term. When time is measured in months, $0 \leq t \leq 47$ is the time period relevant for the calculation of the reference rent in $t=48$. Under the assumption that the same number of dwellings is traded each month, the rent ceiling at $t=48$ is defined as

$$
\bar{R}_{48}=\frac{1.1}{48} \sum_{t=0}^{47} a e^{\gamma t}
$$

If binding, this ceiling leads to an initial drop in rents upon implementation when it is lower than the rent level at the end of the 4-year-period, $R_{47}$, i.e. when $\bar{R}_{48}<a e^{47 \gamma}$. The $\gamma$ that equates this expression is approximately 0.00413, i.e. a growth rate of $0.413 \%$ per month or approximately $4.8 \%$ per year. Below this growth rate, the rent cap should not lead to an immediate drop in the rent level. However, rent increases would be decelerated, from a $4.8 \%$ growth rate to approximately $4.5 \%$ annually on average in the first year after the introduction of the regulation. For $\gamma \approx 0.00395$ (monthly growth rate of $0.395 \%$ ) and less, neither an initial drop, nor a decelerated rent dynamic would be the outcome. ${ }^{7}$

This has implications for the empirical strategy. De facto, markets are only regulated if the previous monthly rent growth exceeds $0.395 \%$. Only in areas that ex-

\footnotetext{
${ }^{7}$ In Sections OB and OA in the Online Appendix, we provide a more detailled description of the mechanism behind the rent cap and estimation results for past rent growth rates in rent cap municipalities. As depicted in Figure 10 in the Online Appendix, there is considerable variation in past rent growth across municipalities.
} 
perienced an average rent growth of at least $0.413 \%$, we do expect to observe an immediate drop in rents.

\section{Empirical analysis}

In the empirical analysis, we investigate the short-run effects of the German rent cap. Primarily, we seek to establish the opposite-sign spillover to free-market rents.

To disentangle general market dynamics from the effects of the rent cap, we start with a difference-in-differences approach that identifies a relative effect between controlled and free-market rents. Then, we decompose this effect into a reduction of rents in the controlled segment and an increase of rents in the free-market segment, using an RDiT design. Additional identifying variation stems from the state-, and in some cases, city-specific start dates of the rent cap (see Table 1). We then build a propensity score-weighted and trimmed sample of municipalities with and without rent cap, establishing similar results by comparing units from treated and untreated municipalities. Finally, we consider short-run supply and demand reactions, where we also make use of this weighted and trimmed sample.

\subsection{Effects on rents}

The results presented in this section rely on advertised rents for dwellings offered on three large online market-places between July 2011 and November 2016: Immonet, Immowelt, and Immobilienscout24. Each dwelling's month of offer and postal code is available in the data, together with a long list of housing characteristics. A detailed description of the data is presented in the Appendix. Although concluded rents would be preferable, the alternative of surveyed rents also has shortcomings: not only are sample sizes typically small, there might also be reporting errors and selection issues, along with the fact that typically spatio-temporal information in these data are much lower. Moreover, such surveys do not always include the (exact) date the household moved into the dwelling, meaning that they do not necessarily represent current market rents. 


\subsubsection{Rents in young and new units}

First, we compare the time trends of rents within regulated postal code districts for dwellings that were recently (re-)built - these units are unregulated and serve as the control group - and regulated units that are between two and ten years old (treatment group). Two variables indicate whether a dwelling is new: the year of construction and a "first time use" dummy. We define a unit as "regulated" if building age is greater than zero. Observations with building age greater than zero that are reported as "first time use" are excluded to reduce measurement error.

We compare the monthly growth rates of rents for regulated units - the treatment group - and new units - the control group - around the introduction of the rent cap. This is a difference-in-differences strategy that asks how the rent cap affects the level of rents in treated relative to similar non-treated units. In a regression framework, the strategy translates into the following estimating equations:

$$
\log R_{i}=x_{i} \beta+\rho_{z_{i}}+f\left(t_{i} ; \operatorname{tr}_{i}\right)+\delta_{0} \operatorname{tr}_{i}+\delta_{1} \text { rent } \operatorname{cap}_{t_{i}}+\delta_{2}\left(\operatorname{tr}_{i} \times \operatorname{rent} \operatorname{cap}_{t_{i}}\right)+\eta_{i},
$$

where $\rho_{z_{i}}$ is a postal code-fixed effect. $\operatorname{tr}_{i}=1$ if the observation belongs to the treatment group and rent $\operatorname{cap}_{t_{i}}=1$ if the rent cap was effective in month $t_{i} . f\left(t_{i} ; \operatorname{tr}_{i}\right)$ is a cubic B-spline with six equidistant "knots" (interval boundaries) located at months $10,20, \ldots, 60$ of the sample period (months 1-65) that is estimated separately for treatment and control observations. ${ }^{8}$ B-splines are "piecewise" polynomials fitted on a near-orthogonal base that allow coefficients to change at each knot. To avoid unrealistic spikes in the fit, splines impose additional restrictions on the first (quadratic splines) and second derivative (cubic splines) at the interval boundaries, resulting in a differentiable fitted line that resembles a higher-order polynomial, but consumes considerably fewer degrees of freedom. Because of their flexibility in a (small) window around the treatment date, where splines capture continuous changes in the trends of treatment and control groups quite well, they help to identify $\delta_{1}$ and $\delta_{2}$ in a way

\footnotetext{
${ }^{8}$ We also considered quadratic splines, twelve equidistant knots, and polynomials, with similar results (see below). We chose this cubic spline specification because it scored lowest on the Bayes Information Criterion.
} 
similar to a regression discontinuity design. A caveat is the behavior of the fitted line at the end-points where the fit often increases or decreases sharply. The reason is that there are no restrictions on the derivatives at these points, meaning that very few data points can have considerable impact on the fit. Arguably, this also shows up in some of the results presented below (see Berk, 2008, chapter 2 for an introduction to splines).

The (gross) treatment effect is given by $\delta_{2}$. It allows for a sudden drop in rents of regulated units at the activation date, relative to the general change in rents at that date, $\delta_{1}$. This gross effect consists of a net effect on regulated units, $\delta_{2}-\delta_{1}$, and potential spillovers from regulated to unregulated market segments, $\delta_{1}$ (as outlined in Section 2.1). The flexible B-splines will also capture more casual spillovers between the groups that are not necessarily related to the rent cap, without identifying these directly. To gauge whether the effects are permanent, one needs to take into account the behavior of the cubic splines over time.

The estimated treatment effects are presented in Table 2, covariate results are in Table 12 in the Online Appendix. Additionally, we provide graphical illustrations of the trend of rents in treatment and control groups (see Figure 5).

Table 2: Regression results: effects on rents, young vs new units

\begin{tabular}{|c|c|c|c|c|}
\hline & \multicolumn{4}{|c|}{ Dependent variable: log rent } \\
\hline & \multicolumn{2}{|c|}{$\begin{array}{l}\text { de facto } \\
\text { regulated areas }\end{array}$} & \multicolumn{2}{|c|}{$\begin{array}{c}\text { de facto } \\
\text { unregulated areas }\end{array}$} \\
\hline & $(1)$ & $(2)$ & (3) & $(4)$ \\
\hline regulated & $\begin{array}{c}0.006 \\
(0.011)\end{array}$ & $\begin{array}{l}-0.010 \\
(0.006)\end{array}$ & $\begin{array}{l}-0.011 \\
(0.006)\end{array}$ & $\begin{array}{c}-0.009^{* *} \\
(0.003)\end{array}$ \\
\hline rent cap effective & $\begin{array}{c}0.010 \\
(0.011)\end{array}$ & & $\begin{array}{c}0.001 \\
(0.008)\end{array}$ & \\
\hline $\begin{array}{l}\text { regulated } \times \\
\text { rent cap effective }\end{array}$ & $\begin{array}{r}-0.033^{*} \\
(0.016)\end{array}$ & $\begin{array}{c}-0.036^{* * *} \\
(0.007)\end{array}$ & $\begin{array}{l}-0.006 \\
(0.009)\end{array}$ & $\begin{array}{r}-0.023^{* * *} \\
(0.004)\end{array}$ \\
\hline $\begin{array}{l}\text { regulated } \times \\
\text { coalition agreement, but law not passed yet }\end{array}$ & & $\begin{array}{l}0.013^{*} \\
(0.007)\end{array}$ & & $\begin{array}{c}0.008 \\
(0.004)\end{array}$ \\
\hline $\begin{array}{l}\text { regulated } \times \\
\text { law passed, but not effective yet }\end{array}$ & & $\begin{array}{c}0.003 \\
(0.011)\end{array}$ & & $\begin{array}{l}-0.007 \\
(0.005)\end{array}$ \\
\hline Adj. $R^{2}$ & 0.891 & 0.891 & 0.891 & 0.891 \\
\hline Observations & 69039 & 69039 & 229460 & 229460 \\
\hline
\end{tabular}


Models (1) and (2) focusses on postal code districts with a de facto binding regulation. The left graph in Figure 5 refers to model (1). It shows that the trends in treatment and control group are nearly identical prior to the date of the coalition agreement.

Remarkably, the lines deviate increasingly after that date, with a stronger rent increase in the treatment group. It seems that landlords of regulated dwellings tried to secure a higher baseline rent before the introduction of the rent cap - the rent cap never requires rent reductions from one tenant to the next. This is in line with a theoretical model of search and matching where landlords trade a higher vacancy risk for higher future rental income streams. At the treatment date, there is a slight (insignificant) increase of $1.1 \%$ in both the treatment and the control group upon activation, but a much larger and highly significant decrease for regulated units once the rent cap was effective in the respective municipality (-3.3\%). Consequently, the net effect on regulated units is about $-2.2 \%$. Figure 5 shows that this difference and remains stable and significant over time. These findings are also supported by model (2), where we remove the cubic splines. In this regression, we control for month fixed effects instead, and allow for different treatment effects in the periods between the coalition agreement, the date when the law passed, and the date when the law became effective on the local level.

Models (3) and (4) are similar to models (1) and (2), but the sample consists of postal code districts where the regulation was de facto not binding. Remarkably, the discrete treatment effect disappears entirely in model (3). However, the corresponding graph in Figure 5 reveals that over time, the difference between the two groups grows steadily, turning significant towards the end of the year 2015. This is also confirmed by model (4), where the treatment effect is highly significant and negative, but about a third smaller in magnitude than the treatment effects from models (1) and (2). ${ }^{9}$

Table 13 in the Appendix reports several alternative specifications for the sub-

\footnotetext{
${ }^{9}$ To assess (beyond Figure 5) whether rents in the two groups followed a common trend prior to the reform, we re-estimate models (2) and (4), but replace the treatment preiod dummies with a full set of month dummies interacted with treatment group status. The coefficients of these interaction terms are plotted in Figure 11 (see Section OC). Clearly, the two groups move in parallel prior to the reform.
} 
Figure 5: Effects of the rent cap on regulated rents

Model 1: High rent growth districts

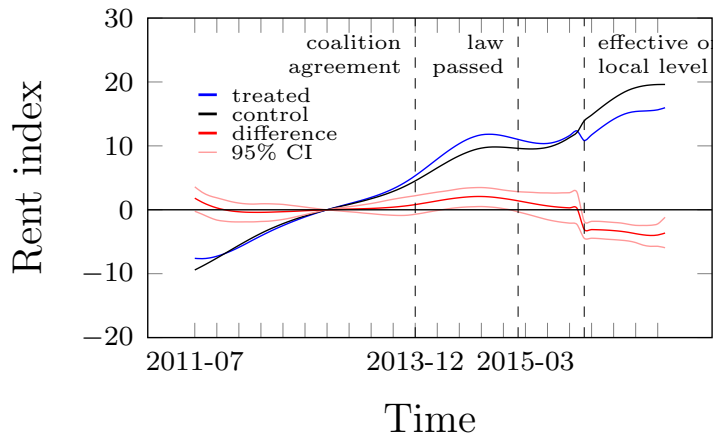

Model 2: Low rent growth districts



sample of postal codes that experienced high past rent growth. Generally, the results are highly robust. The corresponding rent indices are presented in Figure 12. Models R1 to R4 vary the parameters of the B-splines (degree; number and placement of knots), R5 controls for the trend in rents via a (less flexible) $4^{\text {th }}$-order polynomial, with similar results. R6 allows for adjustments prior to the activation of the rent control; this does not change the results qualitatively, but standard errors increase substantially. Furthermore, there does not seem to be a sharp announcement effect for rents.

There is a substantial number of renovated and retrofitted dwellings in the treatment group. If retrofitting or renovation expenses exceed one-third of the construction costs of a comparable new dwelling, these dwellings are temporarily exempt from the regulation. Thus, our results might be biased downwards through false assignments. Therefore, we exclude all units that were offered as renovated or retrofitted in model R7. The treatment effect remains stable.

Finally, there might be sample composition effects. If the share of observations from a postal code district with relatively high rent levels is extraordinarily high in some months - as might be the case if a large construction project is finalized - this would lead to spikes in the growth rate of rents in these postal code districts. As a solution, the sample in model R8 is weighted such that the share of observations from a certain postal code district is stable across all months and, simultaneously, the relative size of the treatment group remains stable in each postal code district. 
While the discrete treatment effect turns insignificant in some of the robustness checks, it remains very stable. Furthermore, according to the graphical results depicted in Figure 12, the difference between rent controlled and uncontrolled units remains significant in all specifications.

\subsubsection{Decomposing the effects on rents}

After having established that the rent cap produced two distinct market segments, we now seek to decompose the relative effect into a rent decrease in controlled units and an increase in uncontrolled units by making use of an RDiT design.

Following the suggestions in Hausman and Rapson (2017), we use a small pre/post treatment window with a fixed duration of six months, and estimate local linear/ quadratic models. Akin to eq. (12) above, these models regress the log rent of units offered online in the months around the state-specific treatment date, on housing characteristics, a rent cap effective-dummy, and a linear or quadratic polynomial in the time trend (interacted with a full set of state dummies). This setting ensures that locations that were not yet treated serve as a control group for locations that already received the treatment. In some regressions, we shifted forward the post-treatment period and excluded the month the rent cap became effective $(t=0)$ and the month thereafter $(t=1)$.

The first set of regressions deal with the sample of newly built units (building age equals zero). Results are displayed in Panel A of Table 3. Models (1)-(3) use a Gaussian kernel that is proportional to $\exp \left(-0.5(x / 2)^{2}\right)$, where $x$ is the distance to the treatment date/window. This kernel assigns more weight to observations closer to the treatment date. In model (1), the treatment effect is measured in the same month that the rent cap was introduced at the local level. Then, it is positive, but insignificant and small. This is also true when $t=0$ is dropped and the treatment effect is measured in the first month after the rent cap became effective; see model (2). When dropping $t=0$ and $t=1$ at the same time in model (3), the effect increases substantially and it is highly significant. This result is robust to adding a state-specific quadratic term in the time trend and using a uniform (model 4) or Gaussian kernel (model 5). It is slightly larger when considering only observations from areas of high past rent growth (model 6). 
Panel B of Table 3 repeats the exercise with the sample of controlled units. Here, we include buildings of all vintages that are at least two years old. The treatment effect is significantly negative and remarkably stable across specifications, already happening in the month the rent cap became effective.

Table 3: Decomposing the rent effects: local linear/ quadratic estimation

\begin{tabular}{|c|c|c|c|c|c|c|}
\hline \multicolumn{7}{|c|}{ Panel A. Newly built, uncontrolled units } \\
\hline & $(1)$ & $(2)$ & $(3)$ & $(4)$ & $(5)$ & $(6)$ \\
\hline rent cap effective & $\begin{array}{c}0.003 \\
(0.006) \\
\end{array}$ & $\begin{array}{c}0.013 \\
(0.008) \\
\end{array}$ & $\begin{array}{c}0.027^{* *} \\
(0.010) \\
\end{array}$ & $\begin{array}{l}0.021^{*} \\
(0.009)\end{array}$ & $\begin{array}{c}0.029^{* *} \\
(0.010) \\
\end{array}$ & $\begin{array}{l}0.033^{*} \\
(0.016)\end{array}$ \\
\hline $\begin{array}{l}\text { Observations } \\
t=0 \text { excluded } \\
t=1 \text { excluded } \\
\text { Trend polynomial } \\
\text { Kernel } \\
\text { Sample }\end{array}$ & $\begin{array}{c}36187 \\
\text { no } \\
\text { no } \\
\text { linear } \\
\text { Gaussian } \\
\text { all } \\
\end{array}$ & $\begin{array}{c}36301 \\
\text { yes } \\
\text { no } \\
\text { linear } \\
\text { Gaussian } \\
\text { all } \\
\end{array}$ & $\begin{array}{c}36353 \\
\text { yes } \\
\text { yes } \\
\text { linear } \\
\text { Gaussian } \\
\text { all } \\
\end{array}$ & $\begin{array}{l}36353 \\
\text { yes } \\
\text { yes } \\
\text { quadratic } \\
\text { uniform } \\
\text { all } \\
\end{array}$ & $\begin{array}{c}36353 \\
\text { yes } \\
\text { yes } \\
\text { quadratic } \\
\text { Gaussian } \\
\text { all }\end{array}$ & $\begin{array}{c}8712 \\
\text { yes } \\
\text { yes } \\
\text { quadratic } \\
\text { Gaussian } \\
\text { high growth } \\
\end{array}$ \\
\hline \multicolumn{7}{|c|}{ Panel B. Rent controlled units } \\
\hline & $(7)$ & $(8)$ & $(9)$ & $(10)$ & $(11)$ & $(12)$ \\
\hline rent cap effective & $\begin{array}{c}-0.014^{* * *} \\
(0.003) \\
\end{array}$ & $\begin{array}{c}-0.009^{* *} \\
(0.003) \\
\end{array}$ & $\begin{array}{c}-0.010^{* *} \\
(0.004) \\
\end{array}$ & $\begin{array}{c}-0.014^{* * *} \\
(0.002) \\
\end{array}$ & $\begin{array}{c}-0.015^{* * *} \\
(0.003) \\
\end{array}$ & $\begin{array}{c}-0.016^{* *} \\
(0.006) \\
\end{array}$ \\
\hline $\begin{array}{l}\text { Observations } \\
t=0 \text { excluded } \\
t=1 \text { excluded } \\
\text { Trend polynomial } \\
\text { Kernel } \\
\text { Sample }\end{array}$ & $\begin{array}{c}179773 \\
\text { no } \\
\text { no } \\
\text { linear } \\
\text { Gaussian } \\
\text { all }\end{array}$ & $\begin{array}{c}184179 \\
\text { yes } \\
\text { no } \\
\text { linear } \\
\text { Gaussian } \\
\text { all }\end{array}$ & $\begin{array}{c}187301 \\
\text { yes } \\
\text { yes } \\
\text { linear } \\
\text { Gaussian } \\
\text { all }\end{array}$ & $\begin{array}{l}179773 \\
\text { yes } \\
\text { yes } \\
\text { quadratic } \\
\text { uniform } \\
\text { all }\end{array}$ & $\begin{array}{l}179773 \\
\text { yes } \\
\text { yes } \\
\text { quadratic } \\
\text { Gaussian } \\
\text { all }\end{array}$ & $\begin{array}{c}42627 \\
\text { yes } \\
\text { yes } \\
\text { quadratic } \\
\text { Gaussian } \\
\text { high growth }\end{array}$ \\
\hline
\end{tabular}

Taken together, these results suggest that the relative effect of -0.033 , as measured by the difference-in-differences design in Section 4.1.1, is very close the relative difference between controlled and uncontrolled units as estimated by the RDiT approach.

In Table 14 in the Appendix, we consider postal codes where past rent growth was low, artificial treatment dates, pseudo-treated municipalities, and log area as the dependent variable. We focus on models 5 (Panel A) and 11 (Panel B) of Table 3. First, we re-estimate the model for postal codes with low past rent growth between 2011 and 2015 (Models 1 and 5, Table 14), finding slightly smaller, but still significant effects than for the sub-sample of high rent growth areas. When estimating treatment effects from a series of artificial treatment dates (models 2 and 6), the mean effect is virtually zero. In each of 2000 repetitions, we hold constant the time pattern of rent cap introductions in the different states (see Table 1) and assign a start date for 
the first adopter state, Berlin, such that we had at least six months of data before and seven (five) months after the date for the sample of uncontrolled (controlled) units. With artificial treatment areas and a series of 2000 random start date patterns (models 3 and 7 ), the results are similar. ${ }^{10}$. The final set of models uses log area as the dependent variable, which leads to an insignificant treatment effect. This supports the view that the observed effects on rents are not driven by a change in the type of units supplied to the market.

As a further robustness check, and in order to prepare the stage for the analysis of supply and demand side effects in Sections 4.3 and 4.2, we re-estimate the effects from a difference-in-difference comparison of rent cap and other municipalities. To make the two groups comparable, we follow a propensity score-weighting and -trimming strategy. The propensity score model is described in detail in Section B in the Appendix.

We estimate the following regression:

$$
\begin{aligned}
\log R_{i}= & x_{i} \beta+\rho_{z_{i}}+\psi_{\text {year }_{i}}+\left(\psi_{\text {year }_{i}} \times \operatorname{rent} \operatorname{cap}_{i}\right) \\
& + \text { active }_{t_{i}}+\delta\left(\operatorname{active}_{t_{i}} \times \operatorname{rent} \operatorname{cap}_{i}\right)+\eta_{i}
\end{aligned}
$$

where $x_{i}$ are covariates, $\rho_{z_{i}}$ are postal code and $\psi_{\text {year }_{i}}$ are year fixed effects. active $t_{i}$ is an indicator that is equal to one if the rent cap is active in the federal state and in the month where $i$ was observed $\left(t_{i}\right)$. rent cap $i$ is equal to one if $i$ is from the treatment group and zero otherwise. $\delta$ is the treatment effect. This approach additionally controls for the possibility that the time variation in treatment dates between federal states is endogenous (assuming that the propensity score weighting and trimming procedure was successful). We also ran regressions where $\psi_{\text {year }_{i}}$ was replaced by a cubic spline in the time trend with six knots at months 10 to 60 .

Propensity score weights were set equal to $\hat{p}_{i}\left(1-\hat{p}_{i}\right)$, where $\hat{p}_{i}$ is the predicted probability that the rent cap was implemented in observation $i$ 's municipality. We

\footnotetext{
${ }^{10}$ These areas are a number of cities from the five Federal States that had not introduced the rent cap as of 2016, namely Braunschweig, Chemnitz, Dresden, Halle, Hannover, Leipzig, Magdeburg, Rostock, Saarbrücken, Schwerin, and Wolfsburg.
} 
trim the sample by dropping municipalities where the probability of treatment was below 0.1 or above 0.9 .

The treatment effect estimates are displayed in Table 4. They corroborate the results from the other two approaches. In the sample of new units (building age is zero), rents were higher by 0.038 (0.033, marginally significant) log points on average in rent cap municipalities, once the rent cap became effective (columns 1 and 2). At the same time, rents for regulated units $^{11}$ decreased by 0.018 (0.023) log points (columns 3 and 4). These estimates are in line with the estimates from the other two approaches, suggesting that anticipation effects play only a minor role in the full sample.

Table 4: Decomposition of rent effects: Rent cap and other municipalities

\begin{tabular}{lccccc}
\hline & \multicolumn{2}{c}{ New units } & \multicolumn{2}{c}{ Existing units } \\
\cline { 2 - 3 } \cline { 5 - 6 } & $(1)$ & $(2)$ & & $(3)$ & $(4)$ \\
\hline rent cap effective & -0.004 & -0.006 & & 0.006 & -0.003 \\
$\quad$ in the State & $(0.012)$ & $(0.014)$ & & $(0.004)$ & $(0.006)$ \\
rent cap effective & $0.038^{* *}$ & 0.033 & $-0.018^{* *}$ & $-0.023^{* *}$ \\
in the State $\times$ treatment group & $(0.015)$ & $(0.018)$ & $(0.006)$ & $(0.009)$ \\
\hline Observations & 58885 & 58885 & & 91837 & 91837 \\
Adj. R & 0.884 & 0.885 & 0.909 & 0.910 \\
Treated municipalities & 179 & 179 & 182 & 182 \\
Control municipalities & 356 & 356 & 364 & 364 \\
Year FE control & yes & no & yes & no \\
Year FE treated & yes & no & yes & no \\
Trend B-Spline control & no & yes & no & yes \\
Trend B-Spline treated & no & yes & no & yes \\
\hline
\end{tabular}

Treatment and control groups were formed by propensity score weighting and trimming. The existing units (columns (3) and (4)) are two to ten years old. Postal code clustered standard errors in parentheses, ${ }^{* * *}: p<.001,{ }^{* *}: p<.01,{ }^{*}: p<.05$.

In the Supplementary Material (see Section OC), we provide a graph of an event study-version of the regressions, where we included a full set of dummies for treatmentquarters (quarters until/since treatment) and an interaction of these dummies with the treatment group indicator. Figure 15 shows the coefficients of these interactions for 16 pre-treatment quarters and six quarters into the treatment. The rent development for new units in the two groups was clearly aligned before the rent cap was introduced in 2015 (a). Moreover, the effect becomes larger several months into the

\footnotetext{
${ }^{11}$ Here, the sample consists of units that are at two to ten years old, not offered as first time use, refurbished, renovated, run-down, or in need of renovation.
} 
treatment period. The graph for units that are two to ten years old (b) reveals a deviation from the common trends assumption in this group. Nonetheless, there is a clear negative effect in the first quarter of the treatment period.

Interpreted through the lens of our simple theoretical model, the increase of freemarket rents indicates misallocation of households to housing units. The fact that the upward effect on free-market rents is larger than the reduction of rents in rentcontrolled units suggests that misallocation is substantial, relative to the intended effect of lowering the housing costs of households living in rent controlled units.

\subsection{Demand response}

If misallocation is present in the market, this should not only be reflected in rents of regulated and unregulated housing units. The introduction of rent control should also be measurable in migration data. Given that willingness to pay is naturally constrained by income, the observed pattern in the rent dynamics should be reflected by a differential propensity of high- versus middle- to low-income households to move home in cities with rent control. This can be evaluated using regionally disaggregated micro-data from the German Socio-Economic Panel (GSOEP). GSOEP is a representative longitudinal study for Germany, surveying approximately 15,000 households annually since 1984 .

To this end, we estimate a logit model of residential moves within and into regulated markets. The data do not allow for distinguishing between moves into regulated and unregulated dwellings. Thus we compare the residential move patterns across regulated and unregulated municipalities. As before, we use a trimmed and weighted sample of municipalities as control group (see section B in the Appendix) where no rent cap is introduced. We estimate a model with a binary dependent variable for residential moves $(m)$ taking the following form:

$$
\begin{aligned}
\operatorname{Pr}\left(m_{i}=1\right)= & x_{i} \beta+\rho_{z_{i}}+\psi_{\text {year }_{i}}+\delta_{1} \operatorname{rent}_{\operatorname{cap}_{j}}+\delta_{2} \operatorname{active}_{t_{j}}+\delta_{3} \operatorname{active}_{t_{j}} \times \mathrm{Q}_{i}+\delta_{4} \mathrm{Q}_{i} \\
& +\delta_{5} \operatorname{rent}_{\mathrm{cap}_{j}} \times \operatorname{active}_{t_{j}}+\delta_{6} \operatorname{rent}_{\mathrm{cap}_{j}} \times \mathrm{Q}_{i} \\
& +\delta_{7} \operatorname{active}_{t_{j}} \times \mathrm{Q}_{i} \times \operatorname{rent} \operatorname{cap}_{j}+\eta_{i}
\end{aligned}
$$


where $x_{i}$ is a set of individual, household, and building characteristics, $\rho_{z_{i}}$ are spatial fixed effects, $\psi_{\text {year }_{i}}$ are time fixed effects, and $\eta_{i}$ is the error term. active is a variable indicating whether the rent control is active, rent cap indicates whether the rent cap was introduced in the specific municipality, and Q indicates to which quintile of the income distribution individual $i$ belongs to. We are particularly interested in the interaction term of $\mathrm{Q}$, rent cap, and active. Further we estimate the model for short ( $\leq$ 5,000 meter) and long distance moves ( $>$ 5,000 meter). This distinction helps answering the question whether households succeeded in finding a new rental unit nearby, and whether the rent cap affected the ability of households coming from outside the municipality to enter the local housing market. Results are presented in table 5, descriptive statistics, common trends and detailed regression results are documented in the Appendix.

The estimated coefficients imply that the rent cap introduced in 2015 positively affects the probability to find a new rental home in short distance (5,000 meter, i.e. within the regulated market) among the lower 75 percent of the income distribution. This suggests that high income households are crowded out by lower income groups in the competition for regulated dwellings. This is supported by the the results estimated for a restricted sample including only buildings that were constructed before 2014, i.e. regulated buildings. The estimated coefficients show that high income groups are less likely renters of regulated dwellings compared to lower income households.

Although we do not exactly know whether the destination housing unit is rent controlled (e.g. refurbished buildings are exempted from the law), this result is fully line with the theoretical explanation, as long as housing services are a normal good (and newer units provide more housing services). High-income households now face more competition for units that are rent controlled, and bid up prices for new, uncontrolled units.

The effect vanishes for high-distance moves (over distances above 5,000 meter). There is neither a general effect, nor an effect on a specific income group. This suggests that the rent cap distorts housing choices of households who move within a city and its surroundings, but does not have large effects on households that enter the region. Overall, these results support the findings from the previous section: it is likely that 
Table 5: Residential moves within and to regulated markets

\begin{tabular}{|c|c|c|c|c|}
\hline & $\begin{array}{l}\text { Model } 1 \\
\text { residential move } \\
\text { short distance } \\
\leq 5,000 \mathrm{~m}\end{array}$ & $\begin{array}{l}\text { Model } 2 \text { (restricted }) \\
\text { residential move } \\
\text { short distance } \\
\leq 5,000 \mathrm{~m}\end{array}$ & $\begin{array}{l}\text { Model } 3 \\
\text { residential move } \\
\text { long distance } \\
>5,000 \mathrm{~m}\end{array}$ & $\begin{array}{c}\text { Model } 4 \text { (restricted) } \\
\text { residential move } \\
\text { long distance } \\
>5,000 \mathrm{~m}\end{array}$ \\
\hline rent cap & $\begin{array}{c}0.353 \\
(0.243)\end{array}$ & $\begin{array}{c}0.473^{*} \\
(0.257)\end{array}$ & $\begin{array}{c}0.309 \\
(0.278)\end{array}$ & $\begin{array}{c}0.247 \\
(0.294)\end{array}$ \\
\hline treatment & $\begin{array}{c}0.269 \\
(0.332)\end{array}$ & $\begin{array}{c}0.282 \\
(0.367)\end{array}$ & $\begin{array}{l}-0.215 \\
(0.396)\end{array}$ & $\begin{array}{l}-0.216 \\
(0.435)\end{array}$ \\
\hline rent cap $\times$ active & $\begin{array}{c}-1.655^{* * * *} \\
(0.591)\end{array}$ & $\begin{array}{c}-1.626^{* *} \\
(0.617)\end{array}$ & $\begin{array}{l}-0.107 \\
(0.517)\end{array}$ & $\begin{array}{l}-0.070 \\
(0.562)\end{array}$ \\
\hline Q1 & $\begin{array}{c}0.925^{* * *} \\
(0.165)\end{array}$ & $\begin{array}{c}1.054^{* * *} \\
(0.179)\end{array}$ & $\begin{array}{c}0.317 \\
(0.167)\end{array}$ & $\begin{array}{c}0.276 \\
(0.172)\end{array}$ \\
\hline Q2 & $\begin{array}{c}0.806^{* * *} \\
(0.164)\end{array}$ & $\begin{array}{c}0.943^{* * *} \\
(0.178)\end{array}$ & $\begin{array}{c}0.291 \\
(0.164)\end{array}$ & $\begin{array}{c}0.256 \\
(0.170)\end{array}$ \\
\hline $\begin{array}{l}\text { Q3 } \\
\text { Q4 }\end{array}$ & $\begin{array}{c}0.651^{* * *} \\
(0.165) \\
\text { (base) }\end{array}$ & $\begin{array}{c}0.732^{* * *} \\
(0.179) \\
\text { (base) }\end{array}$ & $\begin{array}{c}-0.020 \\
(0.174) \\
\text { (base) }\end{array}$ & $\begin{array}{c}-0.077 \\
(0.180) \\
\text { (base) }\end{array}$ \\
\hline rent cap $\times \mathrm{Q} 1$ & $\begin{array}{c}-0.428^{*} \\
(0.205)\end{array}$ & $\begin{array}{l}-0.517^{*} \\
(0.219)\end{array}$ & $\begin{array}{c}0.257 \\
(0.211)\end{array}$ & $\begin{array}{c}0.327 \\
(0.223)\end{array}$ \\
\hline rent cap $\times \mathrm{Q} 2$ & $\begin{array}{c}-0.542^{* *} \\
(0.209)\end{array}$ & $\begin{array}{c}-0.604^{* *} \\
(0.222)\end{array}$ & $\begin{array}{c}0.034 \\
(0.217)\end{array}$ & $\begin{array}{c}0.095 \\
(0.229)\end{array}$ \\
\hline rent cap $\times \mathrm{Q} 3$ & $\begin{array}{c}-0.415^{*} \\
(0.218)\end{array}$ & $\begin{array}{c}-0.478^{*} \\
(0.232)\end{array}$ & $\begin{array}{c}0.242 \\
(0.234)\end{array}$ & $\begin{array}{l}0.407^{*} \\
(0.246)\end{array}$ \\
\hline active $\times \mathrm{Q} 1$ & $\begin{array}{l}-0.229 \\
(0.337)\end{array}$ & $\begin{array}{l}-0.198 \\
(0.370)\end{array}$ & $\begin{array}{c}0.206 \\
(0.395)\end{array}$ & $\begin{array}{c}0.345 \\
(0.428)\end{array}$ \\
\hline active $\times \mathrm{Q} 2$ & $\begin{array}{l}-0.421 \\
(0.346)\end{array}$ & $\begin{array}{l}-0.484 \\
(0.380)\end{array}$ & $\begin{array}{l}-0.141 \\
(0.411)\end{array}$ & $\begin{array}{l}-0.141 \\
(0.454)\end{array}$ \\
\hline active $\times \mathrm{Q} 3$ & $\begin{array}{l}-0.335 \\
(0.362)\end{array}$ & $\begin{array}{l}-0.298 \\
(0.394)\end{array}$ & $\begin{array}{c}0.292 \\
(0.428)\end{array}$ & $\begin{array}{c}0.335 \\
(0.470)\end{array}$ \\
\hline rent cap $\times$ active $\times \mathrm{Q} 1$ & $\begin{array}{l}1.406^{*} \\
(0.594)\end{array}$ & $\begin{array}{l}1.239^{*} \\
(0.622)\end{array}$ & $\begin{array}{l}-0.499 \\
(0.523)\end{array}$ & $\begin{array}{l}-0.726 \\
(0.563)\end{array}$ \\
\hline rent cap $\times$ active $\times Q 2$ & $\begin{array}{l}1.358^{*} \\
(0.610)\end{array}$ & $\begin{array}{c}1.225 \\
(0.640)\end{array}$ & $\begin{array}{l}-0.610 \\
(0.569)\end{array}$ & $\begin{array}{l}-0.801 \\
(0.626)\end{array}$ \\
\hline rent cap $\times$ active $\times \mathrm{Q} 3$ & $\begin{array}{l}1.246^{*} \\
(0.631)\end{array}$ & $\begin{array}{c}1.031 \\
(0.662)\end{array}$ & $\begin{array}{l}-0.372 \\
(0.568)\end{array}$ & $\begin{array}{l}-0.614 \\
(0.615)\end{array}$ \\
\hline housing characteristics & yes & yes & yes & yes \\
\hline household characteristics & yes & yes & yes & yes \\
\hline spatial fixed effects & yes & yes & yes & yes \\
\hline time fixed effects & yes & yes & yes & yes \\
\hline $\mathrm{N}$ & 35,981 & 35,792 & 35,238 & 35,110 \\
\hline Pseudo R2 & 0.04 & 0.05 & 0.09 & 0.10 \\
\hline Chi2 & 525.5 & 655.343 & $1,038.9$ & $1,070.2$ \\
\hline $\mathrm{AIC}$ & $3,118.1$ & $2,894.2$ & $2,307.4$ & $2,151.1$ \\
\hline
\end{tabular}

Clustered standard errors in parentheses, ${ }^{* * *}: p<.001,^{* *}: p<.01,{ }^{*}: p<.05$.

the introduction of the rent cap is accompanied by a substantial misallocation of households. 


\subsection{Supply response}

The preceding sections show that the rent cap had the intended effects on regulated rents and residential moves. It also documents a spillover to rents of uncontrolled units in response to the regulation, as suggested by the theoretical framework. These effects can give rise to supply responses, such as the demolition of existing residential buildings, reduced maintenance effort in existing units, and new housing supply. There are at least two issues not captured by the theoretical model that make predictions ambiguous. First, investors' long-term expectations about future rent regulation might induce a negative response of new housing supply that counteracts the (short-run) incentive of higher rents in new units. Secondly, under the German rent cap, the individual unit's rent ceiling increases with its quality, its furnishing, and its condition (because the rent ceiling depends on average rents paid for similar units). Thus, there still is an incentive to invest in existing units, while the marginal benefit of a renovation might even increase due to the rent cap.

To tackle these questions, this section deals with supply responses to the rent cap. Since intra-market variation is not available in this case, we compare rent cap municipalities to other municipalities over time. This is precarious, as arguably, the rent cap was imposed on municipalities with particular characteristics, making it less likely that pre-treatment trends in treatment and control groups are similar. Thus, as before, we rely on a propensity score weighting and -trimming approach that cuts down the sample to more comparable cases. The same sample of municipalities was used for the regressions in Table 4.

\subsubsection{Demolitions of residential buildings}

The rent cap reduces returns to existing rental units. At the same time, it makes new units more profitable. Ceteris paribus, these two aspects should, at the margin, increase the likelihood that old buildings ripe for destruction are demolished in order to make room for a new residential building. To investigate this issue, we draw on the administrative Demolition and Conversion Statistic (DCS) for 2008-2016. It contains all demolitions in German municipalities recorded by the building authorities. It is provided by the Statistical Offices of the German Länder. In the sample period, 20082016, 64,529 (91,547) residential (non-residential) buildings were demolished fully or 
partly in Germany. 35,346 of the lost residential buildings were demolished to make room for new residential buildings, in 3,996 distinct municipalities. From here on, we refer only to these demolished residential buildings. We focus on this group because it is of particular interest in the present case, and because no change in local land-use regulation is required in order to rebuild a residential building.

As before, we exclude Lower Saxony from the analysis: Lower Saxony introduced the rent cap only as late as December 2016; it is not clear to what extent this decision was already anticipated by building developers in 2014 or 2015. In the regressions, we restrict the sample to municipalities where at least one demolished building was reported between 2008 and 2016.

In the Appendix, we also plot the trends in treatment and control groups for different building sizes, see Figure 17. When considering all buildings (Panel A), the trends are comparable before the treatment year (which we set to 2014, as before), although the two lines deviate somewhat shortly before the treatment date. After the treatment date, there are considerably more demolitions in rent cap municipalities than in the control group. Panels B-C show that this is entirely due to single- and two-family homes. Here, the two lines are more closely together up until the year 2014, with larger difference thereafter. The other two graphs for medium and large buildings do not show any clear pattern.

We investigate further the effect on small buildings in several regressions. First, we regress the number of demolished units per municipality and year, on municipality fixed effects, two dummies for the years 2015 and 2016, a rent cap indicator, and an interaction of the year dummies with the rent cap indicator. Standard errors are clustered on the municipality level. The results are presented in Table 6. Without weighting (column 1 of Table 6), about 1.2 additional small buildings were demolished in every second municipality in the treatment group in 2016 (relative to the control group). There is no significant effect in 2015. Both coefficients are very stable when moving to the trimmed and weighted sample.

Secondly, Figure 6 plots the full set of year interaction effects (and 95\% confidence bands) from a similar regression as in Table 6, for the weighted and trimmed sample. In this regression, only the year 2016 coefficient is significant (relative to 2014). It is 
Table 6: Effects on demolitions

\begin{tabular}{|c|c|c|}
\hline \multirow[t]{2}{*}{ Dependent variable } & \multicolumn{2}{|c|}{$\begin{array}{c}\text { Demolished buildings } \\
\text { w/ 1-2 units }\end{array}$} \\
\hline & $(1)$ & $(2)$ \\
\hline year 2015 & $\begin{array}{l}0.29^{*} \\
(0.14)\end{array}$ & $\begin{array}{c}0.28 \\
(0.18)\end{array}$ \\
\hline year 2016 & $\begin{array}{c}0.10 \\
(0.15)\end{array}$ & $\begin{array}{c}0.04 \\
(0.18)\end{array}$ \\
\hline year $2015 \times$ rent cap & $\begin{array}{c}0.20 \\
(0.27)\end{array}$ & $\begin{array}{c}0.20 \\
(0.31)\end{array}$ \\
\hline year $2016 \times$ rent cap & $\begin{array}{l}0.71^{*} \\
(0.29) \\
\end{array}$ & $\begin{array}{l}0.75^{*} \\
(0.32)\end{array}$ \\
\hline Observations & 4716 & 4716 \\
\hline municipalities & 524 & 524 \\
\hline rent cap municipalities & 181 & 181 \\
\hline weighting and trimming & no & yes \\
\hline
\end{tabular}

Figure 6: Event study design: demolitions of small residential buildings



of the same magnitude as in column 2 of Table 6.

Overall, these results suggest that developers reacted to the rent cap by demolishing more small buildings than they would have done otherwise. In the trimmed sample, about three small buildings were demolished, on average, in a rent capmunicipality in 2014. Relative to this number, the effect is large. However, the total mean (median) housing stock in 2011 was roughly 11,100 (3,900) buildings in these municipalities. This means that the negative short-run effects on the supply of housing through demolitions are small. Because single- and two-family homes are typically owner-occupied, the rental stock is even less affected. On the other hand, these demolitions could be a first sign of positive long-run supply effects: developers reacted to 
the increase in rents for newly constructed units. Thus, tt is likely that they will also extend supply through building on vacant lots that have become attractive enough because of the rent regulation.

We can only speculate about the (zero) effect found for larger buildings. As seen in Figure 17, the pre- and post-treatment trends are fairly flat, although there are large year-to-year fluctuations. This makes it more difficult to identify an effect. Moreover, the destruction of larger residential buildings likely requires much more planning and is prone to many more difficulties (e.g., eviction of tenants). This makes short-run responses less likely.

\subsubsection{New housing supply}

In case vacant, buildable, sites are available, the positive effect on rents in newly constructed housing units should push up supply of new housing. To investigate this issue, we use the propensity score-weighted and -trimmed sample and administrative data on housing completions by municipality and year from 2008 to 2017. The results from a set of regressions are displayed in Table 7 . We consider the number of new housing units, new housing units from conversions and additions to existing buildings, the average number of housing units per new residential building, and the average unit size in new-builds.

The regressions in Table 7 control for municipality fixed effects. In none of the regressions, the main coefficients are significant. In the Online Appendix, we plot the coefficients of rent cap $\times$ year interaction terms for 2008 to 2017 for each of the four outcomes, while adding year and municipality fixed effects (see Figure 18). The results reveal a slight positive trend in the difference between rent cap municipalities and the control group for the number of new housing units (column 1 of Table 7). However, when adding a time trend and an interaction with the treatment group indicator to the regressions, the regressions still do not indicate that, throughout the year 2017, the rent cap had a measurable effect on the supply of new housing units.

One potential reason for this result could be inelastic supply of buildable land in rent-controlled areas. Relying on a propensity score weighting and trimming approach, Mense et al. (2019) show that land values in Bavaria increased disproportionally in rent cap municipalities in 2016, suggesting that investors were confident 
Table 7: Effects on new housing supply

\begin{tabular}{lcccc}
\hline & $\begin{array}{c}\text { New housing } \\
\text { units }\end{array}$ & $\begin{array}{c}\text { Conversions/changes } \\
\text { to the stock }\end{array}$ & $\begin{array}{c}\text { units per new } \\
\text { building }\end{array}$ & $\begin{array}{c}\text { Average } \\
\text { unit size }\end{array}$ \\
\cline { 2 - 5 } & $(1)$ & $(2)$ & $(3)$ & $(4)$ \\
\hline year 2015 & $10.97^{* * *}$ & 0.91 & $0.38^{* * *}$ & $-4.83^{* * *}$ \\
& $(3.08)$ & $(0.52)$ & $(0.08)$ & $(1.22)$ \\
year 2016 & 5.94 & $3.42^{* * *}$ & $0.39^{* * *}$ & -1.85 \\
& $(3.47)$ & $(0.86)$ & $(0.09)$ & $(1.37)$ \\
year 2017 & $13.76^{* * *}$ & $3.95^{* * *}$ & $0.63^{* * *}$ & $-5.15^{*}$ \\
& $(4.24)$ & $(1.07)$ & $(0.10)$ & $(2.05)$ \\
year $2015 \times$ rent cap & 11.64 & -0.54 & 0.19 & 1.30 \\
& $(6.58)$ & $(1.07)$ & $(0.13)$ & $(2.19)$ \\
year $2016 \times$ rent cap & 10.55 & 1.28 & 0.09 & 0.62 \\
& $(7.31)$ & $(2.47)$ & $(0.15)$ & $(2.42)$ \\
year 2017 rent cap & 2.81 & 1.04 & -0.09 & 2.60 \\
& $(7.75)$ & $(2.22)$ & $(0.15)$ & $(2.78)$ \\
\hline Observations & 5550 & 5550 & 5484 & 5484 \\
municipalities & 555 & 555 & 554 & 181 \\
rent cap municipalities & 181 & 181 & 554
\end{tabular}

that the exemption of new buildings from the rent cap is credible. If land supply is inelastic, any additional revenue from higher rents in new-builds (as documented in Section 4.1.2) accrues fully to the land owners and the reaction of land values is comparably strong (as in Mense et al. (2019)). This case is also captured by the simple static model depicted in Figure 8 if the long-run supply curve is very steep.

\subsubsection{Housing quality}

In this section, we address landlords' maintenance effort and effects on the quality of rent-controlled housing units. We rely on the rent data from the propensity score weighted and trimmed sample, estimating linear probability models for all regulated dwellings (not new or substantially retro-fitted). ${ }^{12}$ The main question is whether the rent cap influenced landlords in their maintenance decisions, as is often argued in the literature. Specifically, we model the likelihood that a dwelling was advertised as refurbished or retrofitted, in need of renovation, with a fitted kitchen, and whether the quality of the unit was described as above-average or below-average more often.

The rent control regime discussed in this paper allows free negotiation of rents for the first contract after a substantial refurbishment, if expenses exceed one-third of

\footnotetext{
${ }^{12}$ We estimate linear models because we are interested in average effects and because of the lower computational burden of fixed effects estimation.
} 
today's reconstruction costs of the dwelling. However, there is no such rule for smaller renovations, which are important to keep the quality of buildings constant over time. The individual unit's rent ceiling increases with unit quality and furnishing. Hence, the effect of the rent cap is theoretically ambiguous in our case. The linear probability models presented in Table 8 are akin to the regressions displayed in Table 4, with the main qualification that the left-hand side variables are binary indicators rather than the log rent. We restrict the sample to units that are at least ten years old, because maintenance is less important for younger units.

Table 8: Linear probability models: housing quality response

\begin{tabular}{|c|c|c|c|c|c|c|}
\hline \multirow[b]{2}{*}{ Dependent variable } & \multicolumn{3}{|c|}{ condition } & \multirow{2}{*}{$\begin{array}{c}\text { furnishing } \\
\text { fitted kitchen } \\
(4)\end{array}$} & \multicolumn{2}{|c|}{ quality } \\
\hline & $\begin{array}{c}\text { refurbished } \\
(1)\end{array}$ & $\begin{array}{c}\text { renovated } \\
(2)\end{array}$ & $\begin{array}{c}\text { needs renov. } \\
(3)\end{array}$ & & $\begin{array}{c}\text { high } \\
(5)\end{array}$ & $\begin{array}{l}\text { low } \\
(6)\end{array}$ \\
\hline $\begin{array}{l}\text { rent cap } \times \\
\text { rent cap effective }\end{array}$ & $\begin{array}{l}-0.004 \\
(0.006)\end{array}$ & $\begin{array}{l}-0.000 \\
(0.005)\end{array}$ & $\begin{array}{l}-0.001 \\
(0.001)\end{array}$ & $\begin{array}{c}0.027^{* * *} \\
(0.007)\end{array}$ & $\begin{array}{c}0.001 \\
(0.004)\end{array}$ & $\begin{array}{l}-0.002 \\
(0.003) \\
\end{array}$ \\
\hline Observations & 732142 & 655545 & 629278 & 773602 & 768778 & 769887 \\
\hline Adj. $R^{2}$ & 0.074 & 0.126 & 0.032 & 0.275 & 0.150 & 0.140 \\
\hline Mean of dependent variable & 0.150 & 0.051 & 0.012 & 0.314 & 0.079 & 0.926 \\
\hline
\end{tabular}

The models in Table 8 include semi-annual time fixed effects and a set of interactions of these effects with the treatment group indicator. The interactions are plotted in Figure 19 in the Online Appendix. Identification of the treatment effect relies on variation in start dates between States, after controlling for these more general time effects. Models (1)-(3) tests whether landlords adjusted refurbishment effort once the rent cap became effective. This does not seem to be the case. After controlling for location fixed effects, and separate half-year fixed effects in treatment and control groups, the share of units offered as refurbished, renovated, or in need of renovation (relative to units in "normal condition") did not change once the rent cap became effective.

In model (4), the dependent variable is presence of a fitted kitchen. Typically, the reference rent tables used to calculate rent ceilings include furnishing and also the presence of a fitted kitchen as a characteristic that allows to demand a higher rent. This preserves the incentive to install fitted kitchens even under rent control. Moreover, the premium for the fitted kitchen is difficult to determine. Thus, it adds to the 
uncertainty about the rent ceiling, making it more difficult for tenants to argue that the particular rent ceiling is lower than the concluded rent. The regression estimate shows that the share of units offered with a fitted kitchen in rent cap municipalities increased by 2.7 percentage points once the rent cap became effective on the local level.

Finally, models (5) and (6) in Table 8 consider quality adjustments. In case renovations become inevitable, a margin of adjustment could be the quality of renovations. The dependent variables are indicators for whether the landlord reported the unit's quality as high (above average) or low (below-average). We do not find evidence for such adjustments, suggesting that the effects of a reduced rental income stream and of the quality-dependent rent ceiling cancel out. Another potential explanation could be that quality differences appear in self-reported quality measures only after an extended period.

\section{Conclusions}

Rent controls are still subject to intense debates among scholars and policy makers. We add to this debate by providing causal empirical evidence for the short run effects of rent controls. Building on variation in treatment dates, a difference-in-differences approach, and a discontinuity in time design, we find that a differentiated, secondgeneration rent control regime reduces rents in the controlled sector, but also leads to rent increases for uncontrolled units. As a consequence of this spillover, we document that rent control reduced the propensity to move house within rent controlled areas, but only among high-income households. Furthermore, the spillover pushes up land values and brings forward demolitions of old, ramshackle buildings. However, we were not able to document additional (or less) construction activity, potentially a consequence of the time lag between demolition and new construction. We also do not find evidence for reduced maintenance effort. The empirical findings are robust to various alternative specifications.

The spillover between the regulated and unregulated markets can be linked to misallocation of households to houses. Rent control allows households with a lower willingness to pay than the equilibrium rent to enter the market, thereby crowding 
out households with higher willingness to pay. These latter households bid up rents in the free market. An opposite-sign spillover from the regulated to the free segment of the housing market can thus be interpreted as an indication of misallocation. While economists frequently mention misallocation of housing as an important argument against rent control, we are the first to provide causal empirical evidence for this type of demand response. Our results also shed light on competing interpretations of misallocation: In our interpretation, rent control benefits households with a low willingness to pay for housing by crowding out groups that have a higher willingness to pay. If willingness to pay and income are correlated, this implies that a millionaire (with very high willingness to pay) living in a rent-controlled unit does not represent misallocation. Thus, misallocation arising from rent control does not necessarily benefit high-income households, as suggested, for instance, in (Glaeser and Luttmer, 2003).

This study has strong implications for policy makers and housing market economist. Rent controls primarily benefit low income groups from within regulated markets, by lowering rents. This might serve as an explanation why such policies are popular among policy makers in urban areas. However, these potential benefits come at a substantial cost, also in the short run: welfare losses arise due to misallocation of households to housing units. This is despite the fact that, in the short run, there do not seem to be negative consequences on new construction or maintenance. While it might thus be tempting to implement rent controls, this should be kept in mind. 


\section{References}

Andersen, H. S. (1998). Motives for investments in housing rehabilitation among private landlords under rent control. Housing Studies 13(2), 177-200.

Arnott, R. (1995). Time for revisionism on rent control. Journal of Economic Perspectives 9(1), 99-120.

Arnott, R., R. Davidson, and D. Pines (1983). Housing quality, maintenance and rehabilitation. The Review of Economic Studies 50(3), 467-494.

Arnott, R. and M. Igarashi (2000). Rent control, mismatch costs and search efficiency. Regional Science and Urban Economics 30(3), 249-288.

Ault, R. and R. Saba (1990). The economic effects of long-term rent control: The case of New York City. The Journal of Real Estate Finance and Economics 3(1), 25-41.

Autor, D. H., C. J. Palmer, and P. A. Pathak (2014). Housing market spillovers: Evidence from the end of rent control in cambridge, massachusetts. Journal of Political Economy 122(3), 661-717.

Autor, D. H., C. J. Palmer, and P. A. Pathak (2017). Gentrification and the Amenity Value of Crime Reductions: Evidence from Rent Deregulation. Working Paper No. 23914, NBER.

Berk, R. A. (2008). Statistical Learning from a Regression Perspective, Volume 14. New York: Springer.

Card, D. and A. B. Krueger (1994). Minimum wages and employment: A case study of the fast-food industry in new jersey and pennsylvania. American Economic Review 84, 772-793.

Cheshire, P. C. and S. Sheppard (1995). On the price of land and the value of amenities. Economica 62(246), 247-267. 
Davis, L. W. and L. Kilian (2011). The allocative cost of price ceilings in the US residential market for natural gas. Journal of Political Economy 119(2), 212-241.

Diamond, R., T. McQuade, and F. Qian (2017). The e ects of rent control expansion on tenants, landlords, and inequality: Evidence from san francisco. Technical report, unpublished Working Paper.

Dube, A., T. W. Lester, and M. Reich (2010). Minimum wage effects across state borders: Estimates using contiguous counties. The Review of Economics and Statistics 92(4), 945-964.

Dube, A., T. W. Lester, and M. Reich (2016). Minimum Wage Shocks, Employment Flows, and Labor Market Frictions. Journal of Labor Economics 34(3), 663-704.

Early, D. and J. Phelps (1999). Rent regulations' pricing effect in the uncontrolled sector: An empirical investigation. Journal of Housing Research 10(2), 267-285.

Early, D. W. (2000). Rent control, rental housing supply, and the distribution of tenant benefits. Journal of Urban Economics 48(2), 185-204.

Fallis, G. and L. B. Smith (1984). Uncontrolled prices in a controlled market: The case of rent controls. The American Economic Review 74(1), 193-200.

Fallis, G. and L. B. Smith (1985). Price effects of rent control on controlled and uncontrolled rental housing in Toronto: A hedonic index approach. The Canadian Journal of Economics / Revue canadienne d'Economique 18(3), 652-659.

Federal Statistical Office (2013). Wirtschaftsrechnungen: Einkommens- und Verbrauchsstichprobe - Wohnverhältnisse privater Haushalte. Fachserie 15, Sonderheft 1. Wiesbaden: Federal Statistical Office.

Glaeser, E. L. (2003). Does rent control reduce segregation? Swedish Economic Policy Review 10, 179-202.

Glaeser, E. L. and E. F. Luttmer (2003). The misallocation of housing under rent control. American Economic Review 93, 1027-1046. 
Goodman, A. C. and T. G. Thibodeau (1998). Housing market segmentation. Journal of housing economics $7(2), 121-143$.

Guerrieri, V., D. Hartley, and E. Hurst (2013). Endogenous gentrification and housing price dynamics. Journal of Public Economics 100, 45-60.

Hausman, C. and D. S. Rapson (2017). Regression discontinuity in time: Considerations for empirical applications. Technical report, National Bureau of Economic Research Working Paper 23602.

Kelly, L. (2015). Renters, first-time buyers and owners - how will the election affect you? The Guardian (April 17, 2015).

Kholodilin, K., J. P. Weber, and S. Sebastian (2018). Rental market regulation over the last 100 years in an international comparison. DIW Weekly Report 8(45), 453-464.

Knaup, H., A. Neubacher, and A.-K. Nezik (2013). Squeezed out: Rocketing rents become election issue in Germany. Spiegel Online International (January 2, 2013).

Knight, J. R. (2002). Listing price, time on market, and ultimate selling price: Causes and effects of listing price changes. Real Estate Economics 30(2), 213-237.

Knight, J. R., C. Sirmans, and G. K. Turnbull (1994). List price signaling and buyer behavior in the housing market. The Journal of Real Estate Finance and Economics 9(3), 177-192.

Kutty, N. K. (1996). The impact of rent control on housing maintenance: A dynamic analysis incorporating European and North American rent regulations. Housing Studies 11(1), 69-88.

Lerbs, O. and S. Sebastian (2015). Mietspiegel aus ökonomischer Sicht — Vorschläge für eine Neuregulierung. Beiträge zur Immobilienwirtschaft 10, 126.

Linneman, P. (1987). The effect of rent control on the distribution of income among New York City renters. Journal of Urban Economics 22(1), 14-34. 
Malpezzi, S. (2003). Hedonic pricing models: A selective and applied review. In T. O. Sullivan and K. Gibbs (Eds.), Housing Economics: Essays in Honour of Duncan Maclennan. Blackwell.

Marks, D. (1984). The effect of rent control on the price of rental housing: an hedonic approach. Land Economics 60(1), 81-94.

McDonald, J. F. and D. P. McMillen (2010). Urban economics and real estate: theory and policy. John Wiley \& Sons.

McFarlane, A. (2003). Rent stabilization and the long-run supply of housing. Regional Science and Urban Economics 33(3), 305-333.

Mense, A., C. Michelsen, and K. Kholodilin (2019). The effects of second-generation rent control on land values. American Economic Association Papers and Proceedings 109 .

Merlo, A. and F. Ortalo-Magné (2004). Bargaining over residential real estate: evidence from England. Journal of Urban Economics 56(2), 192-216.

Moon, C.-G. and J. G. Stotsky (1993). The effect of rent control on housing quality change: A longitudinal analysis. Journal of Political Economy, 1114-1148.

Nagy, J. (1997). Do vacancy decontrol provisions undo rent control? Journal of Urban Economics 42(1), 64-78.

Olsen, E. (1988a). Economics of rent control. Journal of Real Estate Finance and Economics 28, 673-678.

Olsen, E. O. (1988b). What do economists know about the effect of rent control on housing maintenance? The Journal of Real Estate Finance and Economics 1(3), 295-307.

O'Sullivan, A. and R. D. Irwin (2007). Urban Economics. McGraw-Hill/Irwin.

Sims, D. P. (2007). Out of control: What can we learn from the end of Massachusetts rent control? Journal of Urban Economics 61, 129-151. 
Skak, M. and G. Bloze (2013). Rent control and misallocation. Urban Studies 50(10), 1988-2005.

Smith, L. B. (1988). An economic assessment of rent controls: The Ontario experience. Journal of Real Estate Finance and Economics 1, 217-231.

Stewart, M. B. (2004). The employment effects of the national minimum wage. The Economic Journal 114(494), C110-C116.

Turner, B. and S. Malpezzi (2003). A review of empirical evidence on the costs and benefits of rent control. Swedish Economic Policy Review 10, 11-56.

Von Hoffman, A. (2000). A study in contradictions: The origins and legacy of the housing act of 1949. Housing policy debate 11(2), 299-326.

Wang, S.-Y. (2011). State Misallocation and Housing Prices: Theory and Evidence from China. American Economic Review 101(5), 2081-2107.

Wilson, W. (2017). Private rented housing: the rent control debate. Technical report, Commons Library Briefing, 3 April 2017. 


\section{Appendix}

\section{A. Rent data}

Data sources and data quality. The rent and house price data used in this study are advertised rents and prices for dwellings from three large online real estate market places: Immonet, Immowelt, and Immobilienscout24. There can be significant differences between the transaction price and a first offer, but the literature points out that systematic mis-pricing can be very costly for sellers of real estate (Knight et al., 1994; Knight, 2002; Merlo and Ortalo-Magné, 2004).

Sample and covariates. The rents sample cover the period from July 2011 to November 2016, allowing us to examine the initial phase of introduction of the rent cap throughout 2015 and 2016. A long list of housing characteristics (type and size of the dwelling, number of bathrooms, balcony, fitted kitchen, etc.) and their quality (e.g., past refurbishments etc.) are included, as well as information on the postal code of the dwelling. These variables are often-used controls in hedonic studies, see, e.g., Malpezzi (2003) and Cheshire and Sheppard (1995).

Summary statistics for treatment and control groups for the sub-samples used in the regressions discussed in Section 4.1 are presented in Table 11 in the Online Appendix. Columns 1-3 display covariate means for the sample of new, unregulated units and columns 4-6 display the respective statistics for the sample of young units $(2-10$ years old) that fall under the regulation (separately for all rent cap municipalities and for municipalities from the trimmed sample). The table shows that the different samples are quite comparable with respect to the observable housing characteristics.

In addition to the characteristics of the dwellings, coordinates from the map snapshots that are displayed with every offer on the real estate marketing platforms were used to map observations to regulated and unregulated regions. Wherever the exact address is given, the coordinates refer to this address. In those cases where the address is hidden, these refer to the centroid of a neighborhood the dwelling is located in. Although there is the possibility that individual observations are misclassified as being subject (not being subject) to rent control, we believe that this probability is very small: Often, municipal boundaries are also postal code boundaries and the 
neighborhoods used by the online real estate/rents marketplaces usually are contained in a single municipality.

We added population density on the level of postal codes, based on the latest census (2011) and aggregated from grid-level population data provided by the Federal Statistical Office. 


\section{B. Propensity Score Model}

We use a logit model to estimate propensity scores for the propensity score weighted and trimmed regressions. Dependent variable is a dummy for treatment status (rent cap municipality yes/no). The sample is restricted to municipalities from federal states that adopted the rent cap, giving us 8664 valid cases and 294 rent cap municipalities. We consider variables that characterize the political economy and trends on the local housing market. The law requires that the local housing is "under pressure", suggesting that treated municipalities have lower vacancy rates, higher rents and land prices, and increasing population. Since the rent cap is designed to make renters of existing units better off (relative to owners and renters of new units), we expect that a low homeownership rate makes adoption more likely. Moreover, we add variables that capture land use and density. We also add the number of new housing units per capita prior to the introduction of the rent cap (2008-2013). This allows the propensity score to depend also on unobserved determinants of housing supply.

Table 9: Logit model: German rent cap municipalities

\begin{tabular}{|c|c|c|}
\hline Dependent variable: rent cap municipality dummy & Coef. & robust $\mathrm{SE}$ \\
\hline unemployed per resident & $-47.913^{* * *}$ & 11.501 \\
\hline dummy: unemployed per resident NA & $-17.221^{* * *}$ & 1.125 \\
\hline population density & $-0.122^{*}$ & 0.053 \\
\hline residential area share & $7.348^{* * *}$ & 1.861 \\
\hline homeownership rate & $-11.031^{* * *}$ & 1.915 \\
\hline dummy: homeownership rate NA & $-21.080^{* * *}$ & 1.266 \\
\hline vacancy rate & $-40.028^{* * *}$ & 6.313 \\
\hline dummy: vacancy rate NA & $-23.055^{* * *}$ & 2.558 \\
\hline units per residential building & 0.366 & 0.409 \\
\hline dummy: units per residential building NA & $-12.458^{* * *}$ & 0.890 \\
\hline avg. land price 2010-2012 (district-level) & $0.009^{* * *}$ & 0.001 \\
\hline change of land price, (1995-1997) vs (2010-2012) & $0.005^{*}$ & 0.002 \\
\hline dummy: land prices NA & 0.576 & 0.444 \\
\hline population growth rate, $2011-2013$ & 10.046 & 5.809 \\
\hline dummy: population growth rate NA & $14.553^{* * *}$ & 2.256 \\
\hline median rent per $\mathrm{m}^{2}$, growth rate, $2011-2013$ & $2.006^{*}$ & 0.803 \\
\hline dummy: rent growth rate NA & $-0.752^{* *}$ & 0.270 \\
\hline new housing units per capita, 2008-2013 & $167.651^{* * *}$ & 31.014 \\
\hline Observations & 8664 & \\
\hline Rent cap municipalities & 294 & \\
\hline
\end{tabular}

The estimation results are depicted in Table 9. A lower vacancy rate, higher and increasing land prices, higher rents, as well as a lower homeownership rate all 
make it more likely that the rent cap will be introduced in a municipality. Other important predictors are the share of unemployed per resident (with a negative sign) and the residential area share (positive sign). While the change in population is only marginally significant, new housing supply per capita is highly significant, suggesting that the rent cap was introduced in more active local housing markets.

Figure 7 displays kernel density estimates of predicted probabilities (capped at 10 and 90\%), separately for the treatment and control groups. There is considerable overlap, with many treated units having low estimated probabilities, and a sizeable share of control units that are classified as rent cap municipalities by the model. Thus, an important pre-requisite for the propensity score weighting and trimming approach is fulfilled. Although some differences remain, Figures 16 to 19 in the text and in the Online Appendix that the trimmed and weighted groups used in the analysis are comparable across a relatively wide range of important variables prior to the introduction of the rent cap. 
Figure 7: Density of propensity scores from Table 9






\section{For Online Publication}

\section{OA. The specific mechanism of the German rent cap}

To illustrate how the rent cap affects the development of rents in new contracts, consider a situation with four representative rental contracts that are consecutively signed in periods $t=1 \ldots 4$. Each contract is concluded for four periods. Further, we assume an increasing trend of rents in new rental contracts in the periods prior to the introduction of the regulation. In period $t=5$, the rent cap is imposed and rents in all subsequently concluded contracts are capped by the local reference rent, which is calculated as an average of the contracts concluded in the previous four periods plus $10 \%$, unless the dwelling was rented out at a higher rate before. In this case, landlords are allowed to charge a rent equal to the rent in the past contract. The local reference rent is adjusted in each period.

Figure 8: Stylized representation of the effects of the rent cap over time

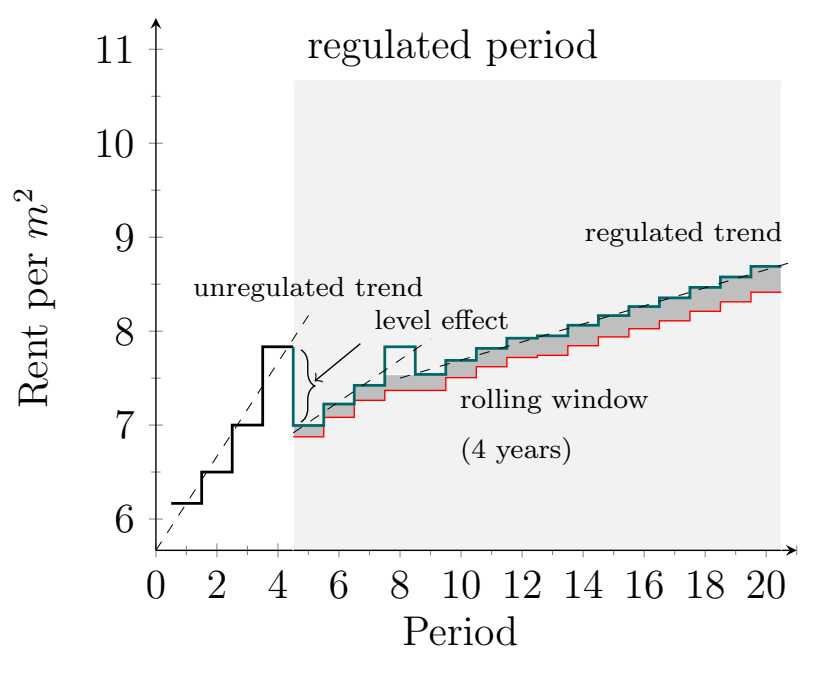

Source: own representation.

In our example, the rents concluded in the first, second, and third periods are below the average of the first four periods and are adjusted to the legal upper bound in periods five to seven. However, as the rent in the contract signed in period four was already above the rent cap level, the landlord is allowed to charge this rent in all 
subsequent contracts. While the introduction of the rent cap leads to an immediate drop of rents in the first regulated period in our example, it becomes obvious from the graphical representation that, in the short-run, there still might be considerable rent increases in year-to-year comparison. However, it also becomes apparent that the dynamics are clearly decelerated (as indicated by the dashed trend lines in Figure 8). In the long-run, rent increases are tied to the dynamics of the local reference rent.

\section{OB. Rent growth prior to the introduction of the rent cap}

The rent cap is de facto binding only if average monthly rent growth in the past 48 months exceeds $0.413 \%$. In this section, we calculate average (constant quality) growth rates on the postal code district level, by running regressions of the form

$$
\log R_{i}=x_{i} \beta+\sum_{z}\left[\rho_{z} d_{z, i}+\gamma_{z} t_{i} \times d_{z, i}\right]+\eta_{i}
$$

on a sample of regulated units offered for rent between July 2011 and May 2015, shortly before the rent cap became effective on the local level. $\log R_{i}$ is the logged net rent per square meter of dwelling $i$ and $x_{i}$ are covariates. $t_{i}$ is the month of observation for $i$ and $d_{z, i}=1$ if $i$ is from postal code $z$. The regression yields (estimated) postal code-specific growth rates for rents, $\gamma_{z}$, that can be contrasted with the critical values derived in Section 3.2 .

Equation (15) was estimated separately for four German regions (south-east, south-west, north-east, north-west) for computational practicability. Results are available on request. Figure 9 below plots the distribution of past rent growth in the sample of rental units. The regulation is not binding for observations to the left of the dashed vertical lines. Only about $23 \%$ of the observations are de facto regulated, i.e. experienced rent growth above $0.413 \%$ : In these districts we would expect an immediate drop in rents. However, note that there is uncertainty on both sides of the market about the true rent ceiling and past rent growth rates from our calculations are also only an approximation.

Figure 10 shows a map of past rent growth by posstal codes. Areas colored in red face a binding rent cap; these are distributed over a large number of cities all over 
Germany.

Figure 9: Density of past monthly growth rates in the rents sample

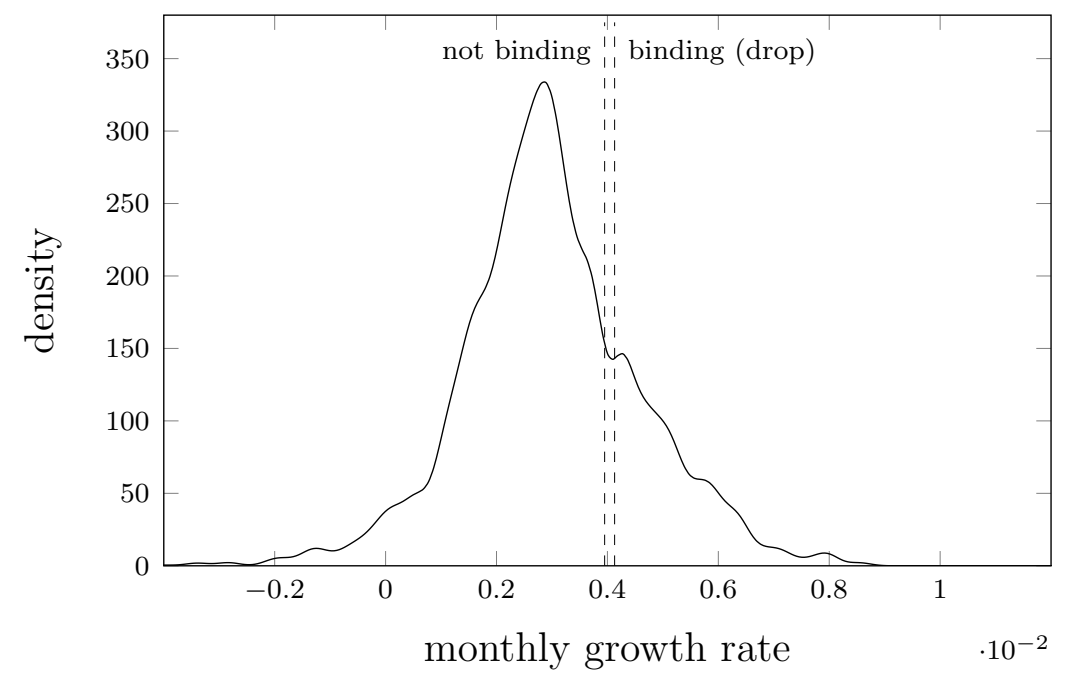

We further characterize postal code districts with a binding rent cap. Table 10 shows results of a linear probability model (column 1) and the corresponding logit model (column 2) of regressions of treatment status (binding/not binding) on the median house price per $\mathrm{m}^{2}$ (as a proxy for local wealth), the vacancy rate, population density, the share of the population under 18, above 65, and the share of foreigners. House prices are calculated from listing prices of dwellings offered for sale in 2011. The other variables were aggregated to the postal code level from $1 \mathrm{~km}^{2}$ grids (Census 2011). The regressions also include city-region fixed effects, so that the results represent within-city differences.

The regressions show that rent growth was particularly strong in neighborhoods with low 2011 house prices and higher vacancy rates (marginally significant in the logit regression). Specifically, this suggests that the pressure on low-income neighborhoods increased substantially in the years before the regulation. These areas also seem to be somewhat more densely populated (with a negative square term) and the share of the foreign population is higher. The other two indicators, the share of residents under 18 or above 65 , are not correlated with the indicator for above-threshold rent growth. The overall picture that emerges from these regressions is that, on average, the rent 
Figure 10: Postal code districts with a De facto binding and non-binding rent cap, as of June 2016

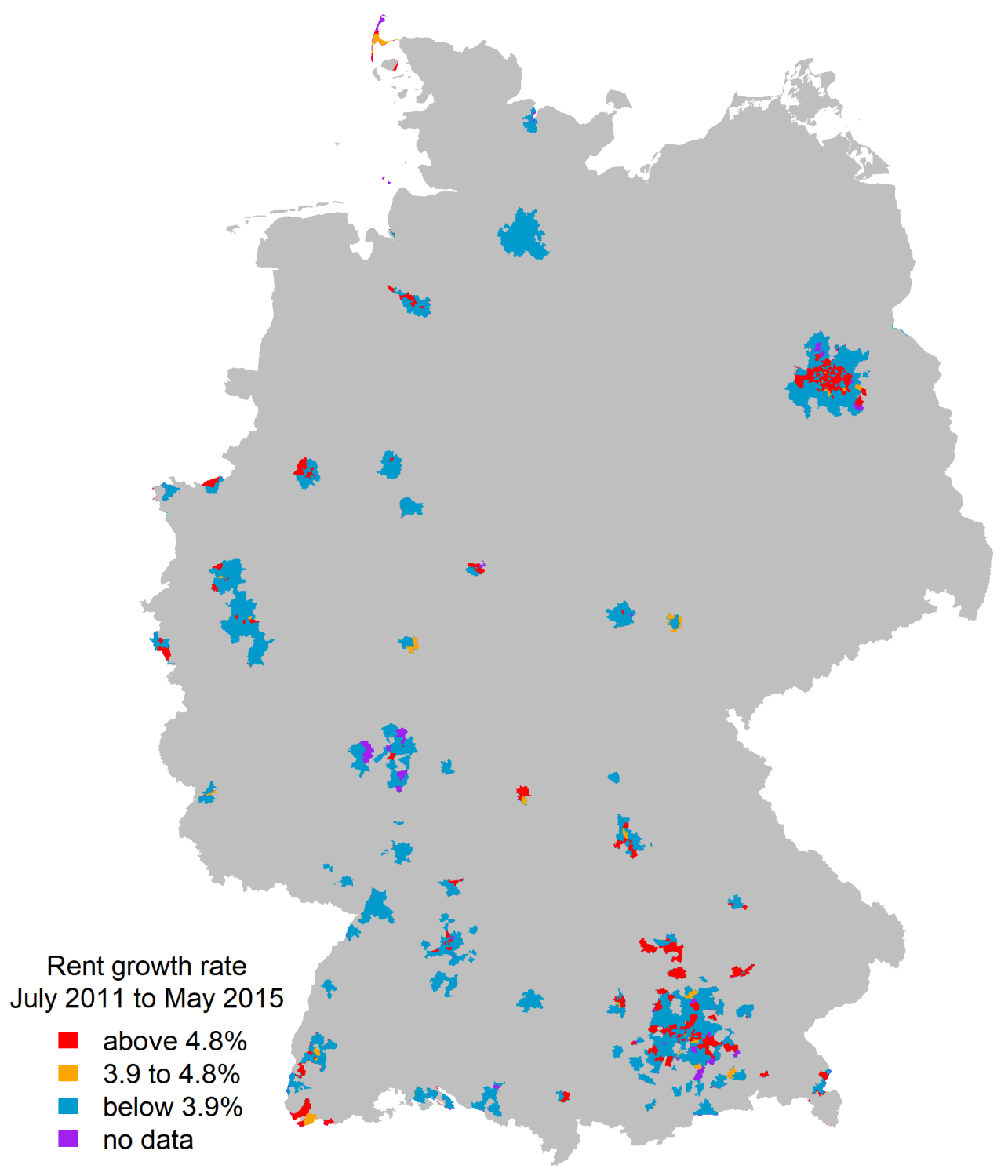

cap reduced rent growth in less affluent areas that served as an overpressure valve for the local rental markets. This is in line with recent evidence on gentrification, see Guerrieri et al. (2013). 
Table 10: Which postal codes face a binding regulation?

\begin{tabular}{|c|c|c|}
\hline \multirow[t]{2}{*}{ Dependent variable: } & \multicolumn{2}{|c|}{ indicator: above-threshold rent growth } \\
\hline & OLS & Logit \\
\hline median house price $/ \mathrm{m}^{2}$ & $\begin{array}{c}-0.057^{* * *} \\
(0.015)\end{array}$ & $\begin{array}{c}-0.532^{* * *} \\
(0.148)\end{array}$ \\
\hline vacancy rate & $\begin{array}{l}0.031^{*} \\
(0.014)\end{array}$ & $\begin{array}{c}0.242 \\
(0.124)\end{array}$ \\
\hline pop density & $\begin{array}{c}0.022^{* * *} \\
(0.006)\end{array}$ & $\begin{array}{c}0.132^{* *} \\
(0.049)\end{array}$ \\
\hline$(\text { pop density })^{2}$ & $\begin{array}{c}-0.001^{* *} \\
(0.000)\end{array}$ & $\begin{array}{c}-0.009^{*} \\
(0.004)\end{array}$ \\
\hline share under 18 & $\begin{array}{c}0.005 \\
(0.005)\end{array}$ & $\begin{array}{c}0.023 \\
(0.048)\end{array}$ \\
\hline share above 65 & $\begin{array}{c}0.003 \\
(0.003)\end{array}$ & $\begin{array}{c}0.005 \\
(0.024)\end{array}$ \\
\hline share foreign & $\begin{array}{c}0.011^{* * *} \\
(0.002) \\
\end{array}$ & $\begin{array}{c}0.088^{* * *} \\
(0.023) \\
\end{array}$ \\
\hline adj. $R^{2}$ & 0.375 & \\
\hline Observations & 974 & 974 \\
\hline Mean dep. var & 0.252 & 0.252 \\
\hline
\end{tabular}

The unit of observation is the postal code. Both models include sub-region fixed effects. The unit of median house prices $/ \mathrm{m}^{2}$ is 1000 Euro. It is calculated from listing prices that were online between July and December 2011, for all postal codes with at least six observations. All other variables were taken from the Census 2011 and were aggregated to postal codes from a $1 \mathrm{~km} \times 1 \mathrm{~km}$ grid. Population density is demeaned. The unit is $1000 \mathrm{inh} . / \mathrm{km}^{2}$.)

Robust standard errors in parentheses, ${ }^{* * *}: p<.001,{ }^{* *}: p<.01,^{*}: p<.05$. 


\section{OC. Effects on rents: additional graphs and tables}

\section{OC.1. Comparison of young and new units within rent cap municipalities}

Table 11: Variable means for regulated and unregulated units

\begin{tabular}{|c|c|c|c|c|c|c|}
\hline \multirow[b]{2}{*}{ municipalities } & \multicolumn{3}{|c|}{ Unregulated - building age zero } & \multicolumn{3}{|c|}{ Regulated - building age 2-10 years } \\
\hline & $\begin{array}{c}\text { all } \\
\text { rent cap }\end{array}$ & $\begin{array}{l}\text { trimmed } \\
\text { rent cap }\end{array}$ & $\begin{array}{c}\text { trimmed } \\
\text { control }\end{array}$ & $\begin{array}{c}\text { all } \\
\text { rent cap }\end{array}$ & $\begin{array}{l}\text { trimmed } \\
\text { rent cap }\end{array}$ & $\begin{array}{c}\text { trimmed } \\
\text { control }\end{array}$ \\
\hline area $\left(\mathrm{m}^{2}\right)$ & 80.82 & 85.88 & 86.91 & 80.45 & 83.55 & 79.80 \\
\hline avgerage room size $\left(\mathrm{m}^{2}\right)$ & 30.68 & 31.24 & 30.31 & 30.59 & 31.08 & 28.79 \\
\hline \# rooms & 2.69 & 2.79 & 2.92 & 2.67 & 2.73 & 2.83 \\
\hline year of construction & 1985.15 & 2006.38 & 2008.87 & 1980.92 & 1986.11 & 1985.55 \\
\hline building age & 0.00 & 0.00 & 0.00 & 4.94 & 5.01 & 5.01 \\
\hline floor & 1.66 & 1.53 & 1.05 & 1.64 & 1.52 & 1.29 \\
\hline floor is NA & 0.21 & 0.31 & 0.32 & 0.20 & 0.25 & 0.23 \\
\hline elevator & 0.41 & 0.60 & 0.49 & 0.39 & 0.40 & 0.24 \\
\hline second bathroom & 0.29 & 0.35 & 0.38 & 0.30 & 0.31 & 0.31 \\
\hline garden use & 0.20 & 0.20 & 0.21 & 0.21 & 0.22 & 0.22 \\
\hline built-in kitchen & 0.39 & 0.48 & 0.29 & 0.51 & 0.54 & 0.40 \\
\hline floor heating & 0.23 & 0.41 & 0.43 & 0.19 & 0.21 & 0.17 \\
\hline self cont'd heating & 0.10 & 0.04 & 0.04 & 0.09 & 0.06 & 0.08 \\
\hline central heating & 0.57 & 0.52 & 0.50 & 0.64 & 0.64 & 0.64 \\
\hline quality: luxury & 0.07 & 0.08 & 0.08 & 0.05 & 0.05 & 0.03 \\
\hline quality: high & 0.42 & 0.39 & 0.46 & 0.37 & 0.32 & 0.34 \\
\hline quality: low & 0.00 & 0.00 & 0.00 & 0.00 & 0.00 & 0.01 \\
\hline type: roof storey & 0.11 & 0.11 & 0.11 & 0.12 & 0.12 & 0.15 \\
\hline type: ground floor & 0.16 & 0.14 & 0.20 & 0.16 & 0.15 & 0.18 \\
\hline type: souterrain & 0.01 & 0.00 & 0.01 & 0.01 & 0.01 & 0.02 \\
\hline type: maisonette & 0.04 & 0.05 & 0.05 & 0.06 & 0.06 & 0.07 \\
\hline type: NA & 0.10 & 0.09 & 0.10 & 0.11 & 0.10 & 0.10 \\
\hline parquet flooring & 0.05 & 0.07 & 0.04 & 0.05 & 0.05 & 0.02 \\
\hline air conditioning & 0.00 & 0.00 & 0.00 & 0.00 & 0.00 & 0.00 \\
\hline parking available & 0.51 & 0.60 & 0.76 & 0.58 & 0.59 & 0.64 \\
\hline balcony or terrace & 0.71 & 0.73 & 0.74 & 0.73 & 0.74 & 0.71 \\
\hline commission payment required & 0.19 & 0.23 & 0.20 & 0.16 & 0.16 & 0.15 \\
\hline Observations & 175841 & 40355 & 18530 & 129624 & 53841 & 37996 \\
\hline
\end{tabular}

Note: The sample of unregulated sale offers is restricted to units for which year of offer equals year of construction, whereas the sample of unregulated rent offers is restricted to buildings with building age equal to zero. The missing categories of the quality and type variables are 'average quality' and 'regular type'. 
Table 12: Covariate results for Table 2: rents

\begin{tabular}{|c|c|c|}
\hline & \multicolumn{2}{|c|}{ Dependent variable: log rent } \\
\hline & (1) & (2) \\
\hline $\log$ area & $\begin{array}{c}0.675^{* * *} \\
(0.017)\end{array}$ & $\begin{array}{c}0.686^{* * *} \\
(0.013)\end{array}$ \\
\hline $\begin{array}{l}\log \text { area } \times \\
\text { population density }\end{array}$ & $\begin{array}{c}0.000^{* * * *} \\
(0.000)\end{array}$ & $\begin{array}{c}0.000^{* * * *} \\
(0.000)\end{array}$ \\
\hline avgerage room size & $\begin{array}{c}0.003^{* * *} \\
(0.000)\end{array}$ & $\begin{array}{c}0.003^{* * *} \\
(0.001)\end{array}$ \\
\hline \# rooms & $\begin{array}{c}0.068^{* * *} \\
(0.005)\end{array}$ & $\begin{array}{c}0.069^{* * *} \\
(0.004)\end{array}$ \\
\hline constructed $1800-1918$ & $\begin{array}{c}-0.027^{* * *} \\
(0.007)\end{array}$ & $\begin{array}{c}-0.049^{* * *} \\
(0.004)\end{array}$ \\
\hline constructed $1919-1945$ & $\begin{array}{c}-0.074^{* * *} \\
(0.008)\end{array}$ & $\begin{array}{c}-0.089^{* * *} \\
(0.004)\end{array}$ \\
\hline constructed 1946-1965 & $\begin{array}{c}-0.102^{* * *} \\
(0.008)\end{array}$ & $\begin{array}{c}-0.118^{* * *} \\
(0.004)\end{array}$ \\
\hline constructed 1966-1975 & $\begin{array}{c}-0.114^{* * *} \\
(0.006)\end{array}$ & $\begin{array}{c}-0.136^{* * *} \\
(0.004)\end{array}$ \\
\hline constructed $1976-1985$ & $\begin{array}{l}-0.124^{* * *} \\
(0.008)\end{array}$ & $\begin{array}{c}-0.125^{* * *} \\
(0.003)\end{array}$ \\
\hline constructed 1986-1990 & $\begin{array}{c}-0.103^{* * *} \\
(0.011)\end{array}$ & $\begin{array}{c}-0.100^{* * *} \\
(0.004)\end{array}$ \\
\hline constructed 1991-2000 & $\begin{array}{c}-0.118^{* * * *} \\
(0.011)\end{array}$ & $\begin{array}{c}-0.147^{* * *} \\
(0.010)\end{array}$ \\
\hline constructed 2001-2005 & $\begin{array}{c}0.003 \\
(0.014)\end{array}$ & $\begin{array}{c}-0.039^{* * *} \\
(0.005)\end{array}$ \\
\hline constructed 2006-2010 & $\begin{array}{l}-0.000 \\
(0.010)\end{array}$ & $\begin{array}{l}-0.016^{* * *} \\
(0.004)\end{array}$ \\
\hline building age & $\begin{array}{c}-0.007^{* * *} \\
(0.001)\end{array}$ & $\begin{array}{c}-0.004^{* * *} \\
(0.000)\end{array}$ \\
\hline floor & $\begin{array}{l}-0.001 \\
(0.001)\end{array}$ & $\begin{array}{l}-0.001 \\
(0.001)\end{array}$ \\
\hline floor is NA & $\begin{array}{c}0.043^{* * *} \\
(0.004)\end{array}$ & $\begin{array}{c}0.035^{* * *} \\
(0.003)\end{array}$ \\
\hline elevator & $\begin{array}{c}0.018^{* * *} \\
(0.005)\end{array}$ & $\begin{array}{c}0.016^{* * *} \\
(0.003)\end{array}$ \\
\hline $\begin{array}{l}\text { floor } \times \\
\text { elevator }\end{array}$ & $\begin{array}{c}0.007^{* * *} \\
(0.001)\end{array}$ & $\begin{array}{c}0.007^{* * *} \\
(0.001)\end{array}$ \\
\hline second bathroom & $\begin{array}{c}0.035^{* * *} \\
(0.003)\end{array}$ & $\begin{array}{c}0.031^{* * *} \\
(0.002)\end{array}$ \\
\hline garden use & $\begin{array}{c}0.017^{* * *} \\
(0.004)\end{array}$ & $\begin{array}{c}0.007^{* * *} \\
(0.002)\end{array}$ \\
\hline built-in kitchen & $\begin{array}{c}0.053^{* * *} \\
(0.003)\end{array}$ & $\begin{array}{c}0.045^{* * *} \\
(0.002)\end{array}$ \\
\hline floor heating & $\begin{array}{c}0.042^{* * *} \\
(0.004)\end{array}$ & $\begin{array}{c}0.048^{* * *} \\
(0.003)\end{array}$ \\
\hline self cont'd heating & $\begin{array}{c}-0.047^{* * * *} \\
(0.005)\end{array}$ & $\begin{array}{c}-0.032^{* * *} \\
(0.003)\end{array}$ \\
\hline central heating & $\begin{array}{l}-0.021^{* * * *} \\
(0.004)\end{array}$ & $\begin{array}{c}-0.008^{* *} \\
(0.003)\end{array}$ \\
\hline condition: renovated & $\begin{array}{c}-0.050^{* * * *} \\
(0.004)\end{array}$ & $\begin{array}{c}-0.041^{* * * *} \\
(0.003)\end{array}$ \\
\hline condition: retrofitted & $\begin{array}{l}-0.010^{*} \\
(0.004)\end{array}$ & $\begin{array}{c}-0.010^{* * * *} \\
(0.002)\end{array}$ \\
\hline quality: luxury & $\begin{array}{c}0.147^{* * *} \\
(0.008)\end{array}$ & $\begin{array}{c}0.133^{* * *} \\
(0.005)\end{array}$ \\
\hline quality: high & $\begin{array}{c}0.053^{* * *} \\
(0.003)\end{array}$ & $\begin{array}{c}0.046^{* * *} \\
(0.002)\end{array}$ \\
\hline quality: low & $\begin{array}{c}-0.109^{* * * *} \\
(0.014)\end{array}$ & $\begin{array}{c}-0.101^{* * * *} \\
(0.009)\end{array}$ \\
\hline type: roof storey & $\begin{array}{c}0.041^{* * *} \\
(0.005)\end{array}$ & $\begin{array}{c}0.008^{* * *} \\
(0.002)\end{array}$ \\
\hline type: ground floor & $\begin{array}{c}-0.021^{* * *} \\
(0.004)\end{array}$ & $\begin{array}{l}-0.003 \\
(0.002)\end{array}$ \\
\hline type: souterrain & $\begin{array}{c}-0.109^{* * * *} \\
(0.015)\end{array}$ & $\begin{array}{c}-0.095^{* * *} \\
(0.005)\end{array}$ \\
\hline type: maisonette & $\begin{array}{c}0.027^{* * *} \\
(0.007)\end{array}$ & $\begin{array}{c}0.023^{* * *} \\
(0.003)\end{array}$ \\
\hline type: NA & $\begin{array}{c}0.001 \\
(0.004)\end{array}$ & $\begin{array}{c}0.010^{* * *} \\
(0.002)\end{array}$ \\
\hline parquet flooring & $\begin{array}{c}0.048^{* * *} \\
(0.006)\end{array}$ & $\begin{array}{c}0.035^{* * *} \\
(0.004)\end{array}$ \\
\hline air conditioning & $\begin{array}{l}0.052^{*} \\
(0.024)\end{array}$ & $\begin{array}{c}0.057^{* * * *} \\
(0.016)\end{array}$ \\
\hline parking available & $\begin{array}{l}0.014^{*} \\
(0.006)\end{array}$ & $\begin{array}{c}0.020^{* * * *} \\
(0.004)\end{array}$ \\
\hline $\begin{array}{l}\text { parking available } \times \\
\text { population density }\end{array}$ & $\begin{array}{c}0.000 \\
(0.000)\end{array}$ & $\begin{array}{c}-0.000^{* *} \\
(0.000)\end{array}$ \\
\hline balcony or terrace & $\begin{array}{c}0.022^{* * *} \\
(0.003)\end{array}$ & $\begin{array}{c}0.014^{* * * *} \\
(0.002)\end{array}$ \\
\hline $\begin{array}{l}\text { commission payment } \\
\text { required }\end{array}$ & $\begin{array}{c}0.024^{* * *} \\
(0.005)\end{array}$ & $\begin{array}{c}0.018^{* * *} \\
(0.002)\end{array}$ \\
\hline
\end{tabular}

Note: Postal code fixed effects and spline coefficients are omitted. The column numbers refer to Table 2. Covariate results for other rent models are available on request, but are omitted here to save space. The omitted categories are buildings constructed after 2010 , average quality, regular dwelling type. Postal code-clustered standard errors in parentheses, ${ }^{* * *}: p<.001,{ }^{* *}: p<.01,^{*}: p<.05$. 


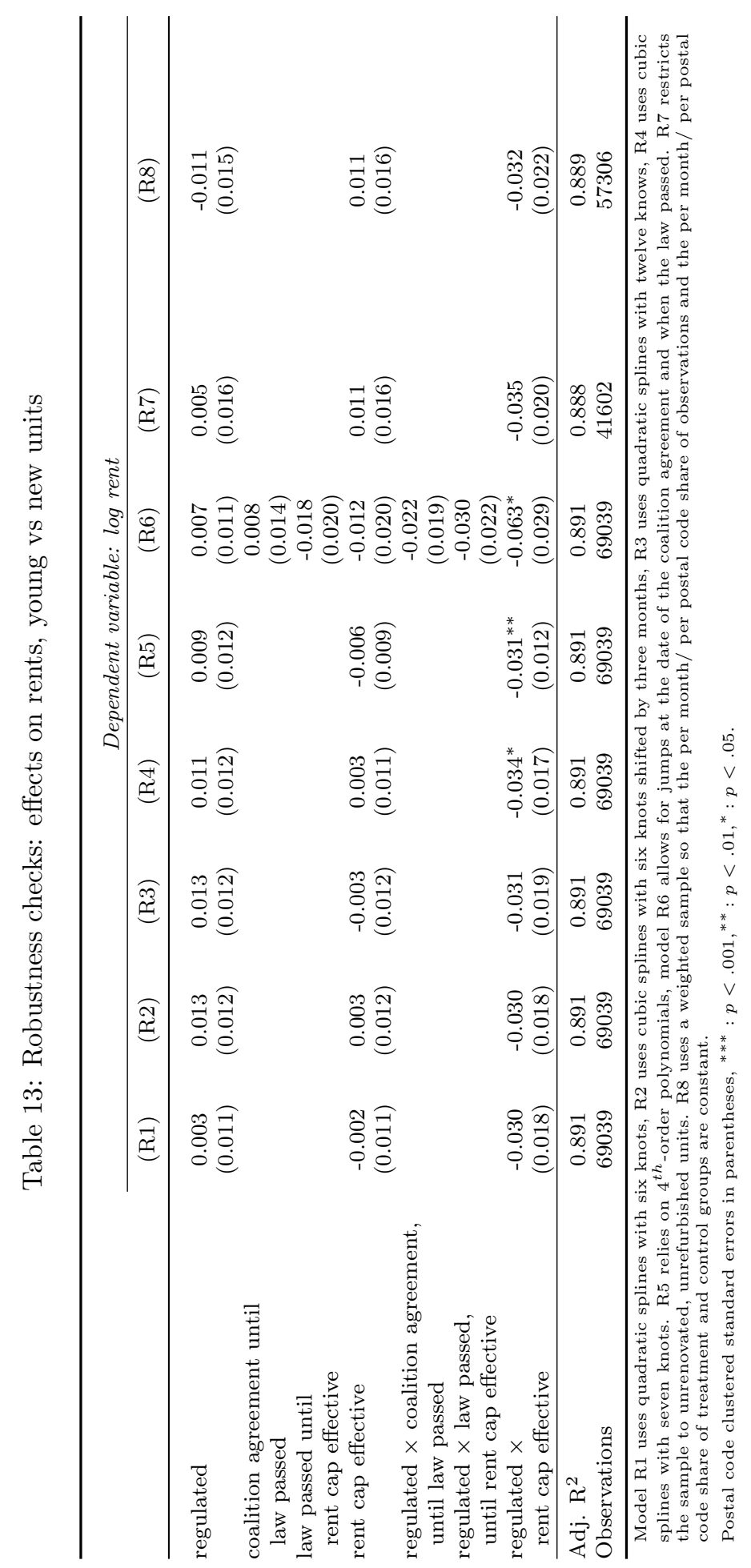


Figure 11: Common trends for regressions in Table 2

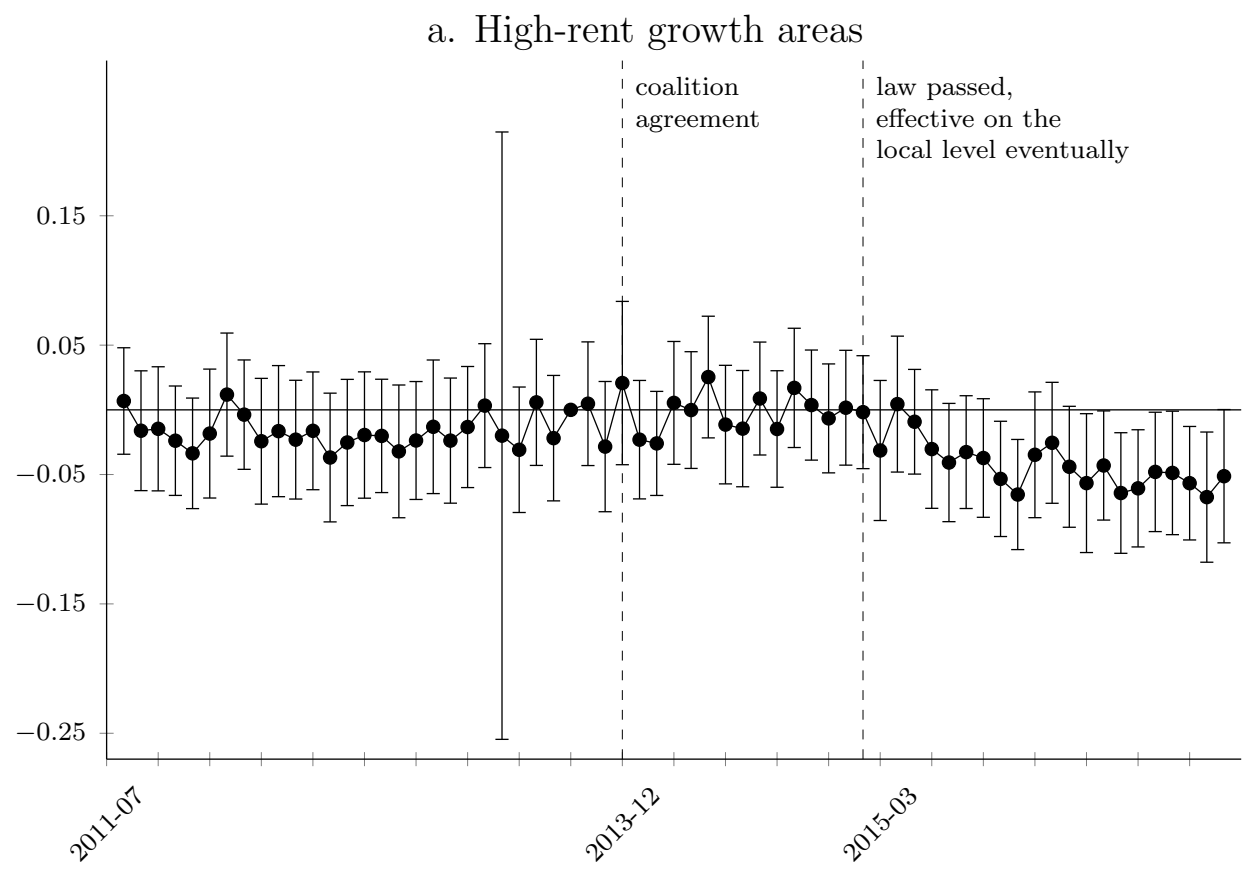

b. Low-rent growth areas

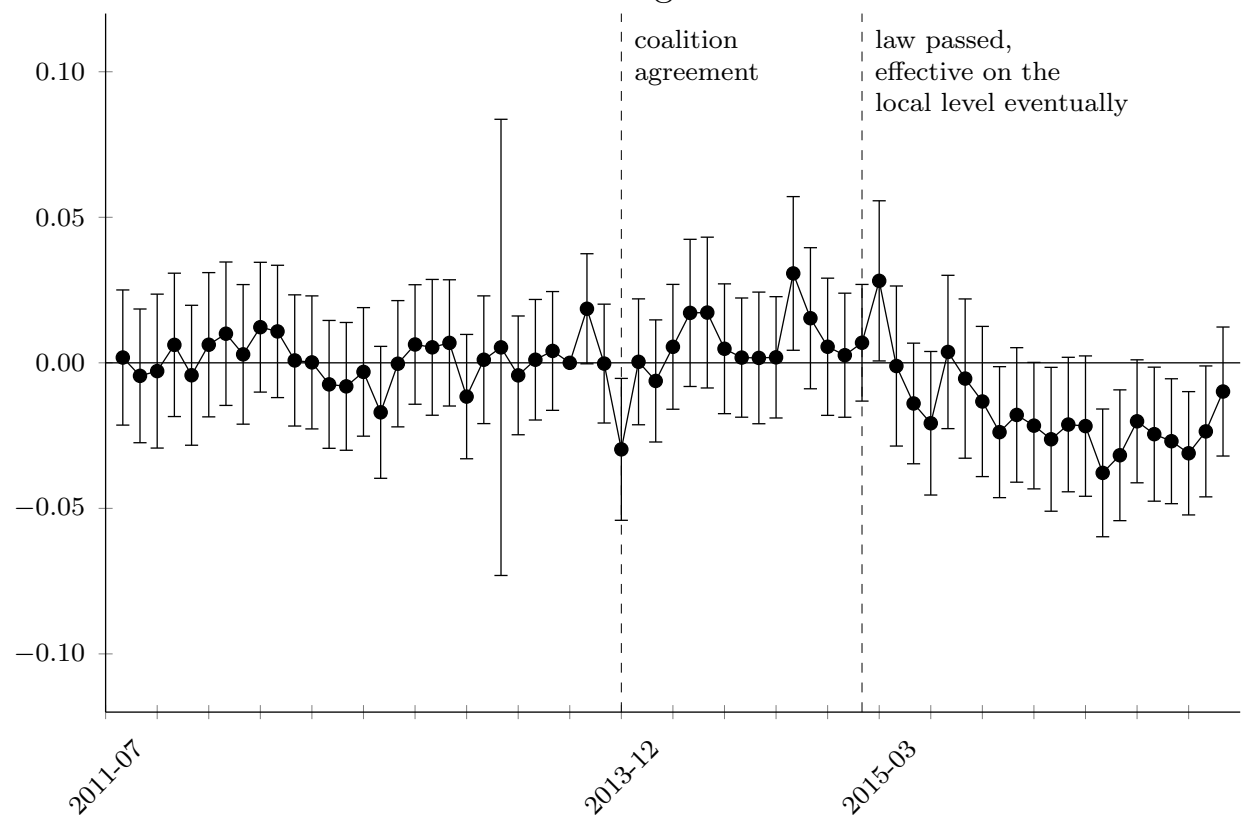




\section{OC.2. Decomposition of the effect on rents}

Table 14: RDiT rent effects: Additional regressions

\begin{tabular}{|c|c|c|c|c|}
\hline & $\begin{array}{l}\text { Low growth areas } \\
(1)\end{array}$ & $\begin{array}{l}\text { Pseudo-treatment dates } \\
(2)^{b}\end{array}$ & $\begin{array}{c}\text { Pseudo-treated areas } \\
(3)^{b}\end{array}$ & $\begin{array}{c}\text { Log area as dep. variable } \\
(4)\end{array}$ \\
\hline rent cap effective & $\begin{array}{c}0.027 \\
(0.012) \\
\end{array}$ & $\begin{array}{l}-0.001 \\
(0.010)\end{array}$ & $\begin{array}{c}0.002 \\
(0.008) \\
\end{array}$ & $\begin{array}{c}0.012 \\
(0.014)\end{array}$ \\
\hline $\begin{array}{l}\text { Observations } \\
\text { Dep. variable } \\
\text { Kernel } \\
\text { Trend polynomial }\end{array}$ & $\begin{array}{c}26824 \\
\log \text { rent } \\
\text { Gaussian } \\
\text { quadratic } \\
\end{array}$ & $\begin{array}{c}26674 \\
\text { log rent } \\
\text { Gaussian } \\
\text { quadratic } \\
\end{array}$ & $\begin{array}{c}6369 \\
\text { log rent } \\
\text { Gaussian } \\
\text { quadratic }\end{array}$ & $\begin{array}{c}36353 \\
\text { log area } \\
\text { Gaussian } \\
\text { quadratic }\end{array}$ \\
\hline \multicolumn{5}{|c|}{ Panel B. Rent controlled units } \\
\hline & $\begin{array}{l}\text { Low growth areas } \\
\qquad 5)^{a}\end{array}$ & $\begin{array}{l}\text { Pseudo-treatment dates } \\
(6)^{a, b}\end{array}$ & $\begin{array}{l}\text { Pseudo-treated areas } \\
(7)^{a}\end{array}$ & $\begin{array}{c}\text { Log area as dep. variable } \\
(8)^{a}\end{array}$ \\
\hline rent cap effective & $\begin{array}{c}-0.014^{* * *} \\
(0.003)\end{array}$ & $\begin{array}{l}-0.000 \\
(0.004)\end{array}$ & $\begin{array}{l}0.000 \\
(0.005)\end{array}$ & $\begin{array}{c}0.005 \\
(0.005)\end{array}$ \\
\hline $\begin{array}{l}\text { Observations } \\
\text { Dep. variable } \\
\text { Kernel } \\
\text { Trend polynomial }\end{array}$ & $\begin{array}{c}133691 \\
\text { log rent } \\
\text { Gaussian } \\
\text { quadratic }\end{array}$ & $\begin{array}{c}129503 \\
\text { log rent } \\
\text { Gaussian } \\
\text { quadratic }\end{array}$ & $\begin{array}{c}38925 \\
\text { log rent } \\
\text { Gaussian } \\
\text { quadratic }\end{array}$ & $\begin{array}{c}179774 \\
\text { log area } \\
\text { Gaussian } \\
\text { quadratic }\end{array}$ \\
\hline \multicolumn{5}{|c|}{$\begin{array}{l}\text { : The regressions also include the scaled building age } \times \text { rent cap active interaction term; its coefficient is not reported here to } \\
\text { improve clarity. } \\
b: \text { The reported coefficients/ standard errors are the empirical medians/ standard deviations of the pseudo-treatment effect estimates. } \\
\text { The number of observations } N \text { is the median number of observations. The standard deviation is pre-multiplied by } \sqrt{N / N_{0}} \text { to make it } \\
\text { comparable to the standard deviation of the respective model from Table ?? in the text, where } N_{0} \text { is the number of observations from } \\
\text { this model. Because } N<N_{0} \text {, this makes it more likely that the point estimate in the regression is large relative to the reported } \\
\text { standard error and thus is a conservative choice. } \\
\text { Postal code clustered standard errors in parentheses, }{ }^{* * *}: p<.001,{ }^{* *}: p<.01,{ }^{*}: p<.05 \text {. }\end{array}$} \\
\hline
\end{tabular}


Figure 12: Robustness checks: effects of the rent cap on regulated rents, see Table 13

Model R1: Quadratic spline, six knots



Model R3: Quadratic spline, twelve knots

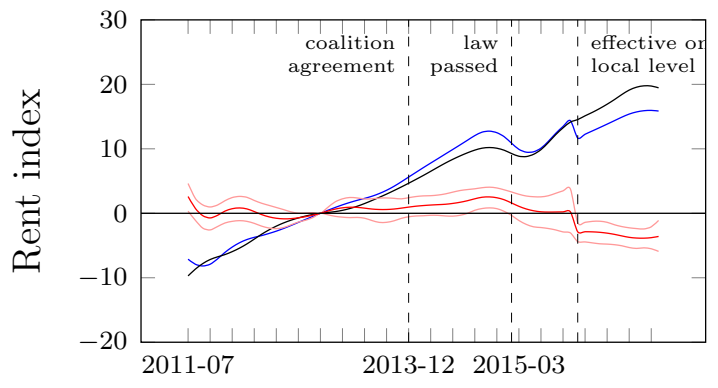

Model R5: $4^{t} h$ order polynomial

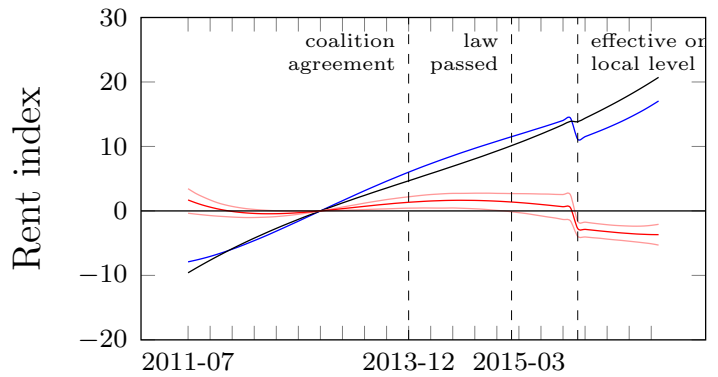

R7: No retrofits in sample



Time
Model R2: Cubic spline, six knots (shifted)



Model R4: Cubic spline, seven knots



Model R6: Flexible treatment

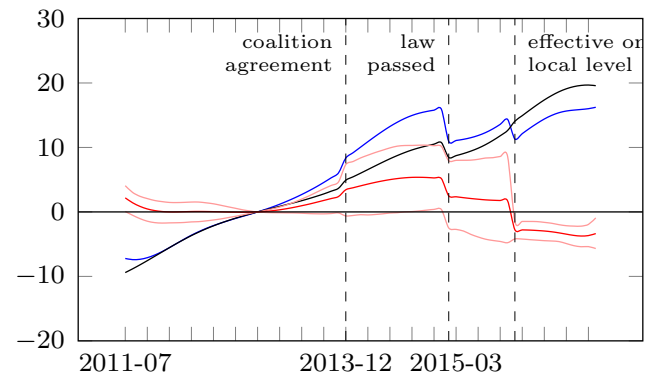

Model R8: Weighted sample

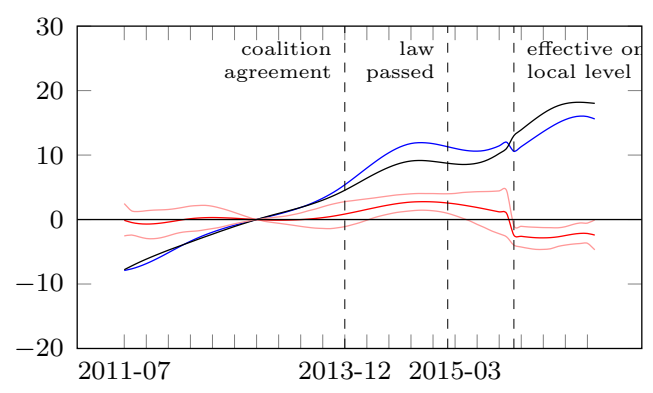

Time 
Figure 13: Binned residuals from the RDiT rents regressions

\section{Panel A. Newly built, uncontrolled units}

(1) Gaussian kernel, linear trend

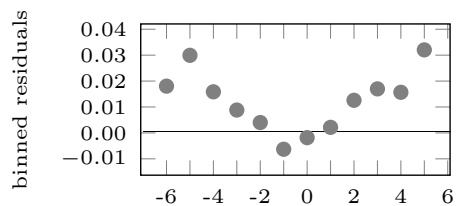

months before/after treatment

(4) Uniform kernel, quadratic trend months 0,1 excluded

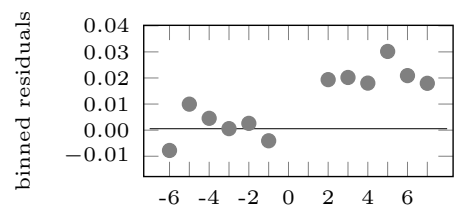

months before/after treatment
(2) Gaussian kernel, linear trend month 0 excluded

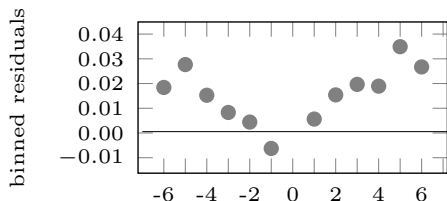

months before/after treatment

(5) Gaussian kernel, quadratic trend months 0,1 excluded



months before/after treatment
(3) Gaussian kernel, linear trend months 0,1 excluded



months before/after treatment

(6) Gauss./quadr., 0,1 excluded high rent growth areas

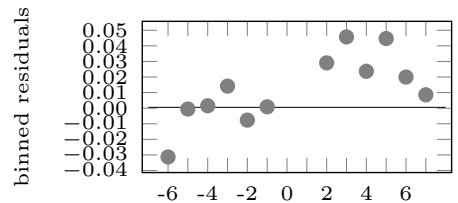

months before/after treatment

\section{Panel B. Rent controlled units}

(1) Gaussian kernel, linear trend

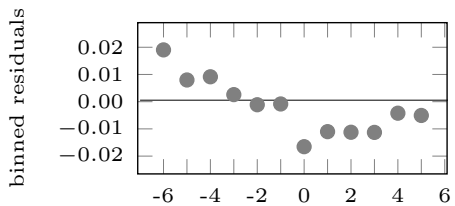

months before/after treatment

(4) Linear kernel, quadratic trend

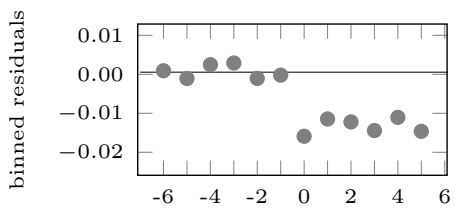

months before/after treatment
(2) Gaussian kernel, linear trend month 0 excluded



months before/after treatment

(5) Gaussian kernel, quadratic trend

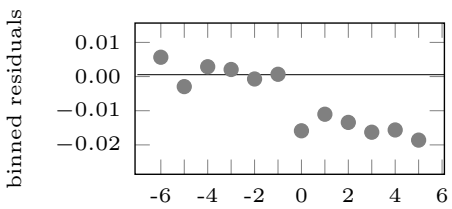

months before/after treatment
(3) Gaussian kernel, linear trend, months 0,1 excluded

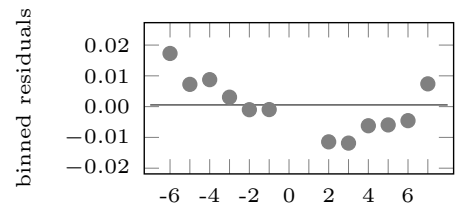

months before/after treatment

The figure shows residual means in each pre- and post-treatment month, for all regressions from Table 3 in the main text. 
Figure 14: Number of observations by month in RDiT rents regressions

(1) Rent controlled units

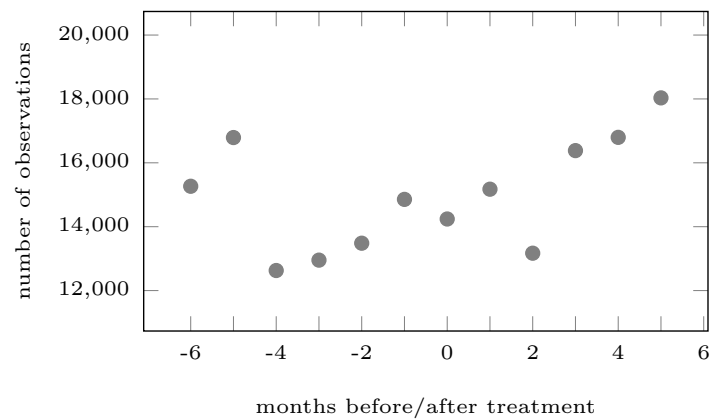

(2) Newly built, uncontrolled units

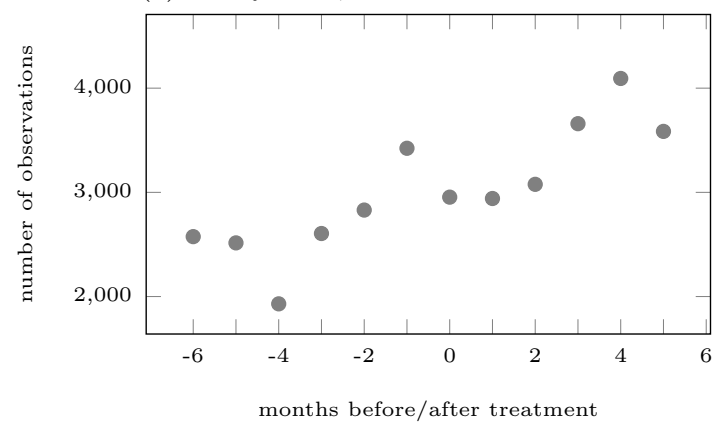

The figure shows the number of observations in each pre- and post-treatment month, for regressions (1) and (7) from Table 3 in the main text. 
Table 15: Means of covariates for Table 5: residential moves

\begin{tabular}{|c|c|}
\hline Variable & Mean \\
\hline residential move & 0,043 \\
\hline rent cap municipality & 0,463 \\
\hline treatment $(2015 \& 2016)$ & 0,145 \\
\hline \multicolumn{2}{|l|}{ individual characteristics } \\
\hline principal tenant & 0,977 \\
\hline subtenant & 0,020 \\
\hline secondary school degree & 0,226 \\
\hline technical college entrance qualification & 0,048 \\
\hline high-school diploma & 0,205 \\
\hline other degree & 0,124 \\
\hline no diploma & 0,041 \\
\hline still in training & 0,028 \\
\hline 1st income quartile (monthly disposable income, Euro) & 975.1631 \\
\hline 2nd income quartile & 2127.753 \\
\hline 3rd income quartile & 3144.788 \\
\hline 4th income quartile & 5755.455 \\
\hline \multicolumn{2}{|l|}{ housing characteristics } \\
\hline Year of construction & 1969,990 \\
\hline flat size & 80,130 \\
\hline No. of rooms & 3,240 \\
\hline monthly net rent & 508,530 \\
\hline monthly heating costs & 85,440 \\
\hline \multicolumn{2}{|l|}{ time fixed effects } \\
\hline 2002 & 0,063 \\
\hline 2003 & 0,064 \\
\hline 2004 & 0,063 \\
\hline 2005 & 0,060 \\
\hline 2006 & 0,057 \\
\hline 2007 & 0,058 \\
\hline 2008 & 0,055 \\
\hline 2009 & 0,050 \\
\hline 2010 & 0,053 \\
\hline 2011 & 0,067 \\
\hline 2012 & 0,076 \\
\hline 2013 & 0,078 \\
\hline 2014 & 0,041 \\
\hline 2015 & 0,072 \\
\hline \multicolumn{2}{|l|}{ spatial controls } \\
\hline Hamburg & 0,101 \\
\hline Bremen & 0,037 \\
\hline Northrhine-Westfalia & 0,342 \\
\hline Hessen & 0,085 \\
\hline Rhineland-Palatinate & 0,043 \\
\hline Baden-Wuerttemberg & 0,143 \\
\hline Bavaria & 0,123 \\
\hline Brandenburg & 0,031 \\
\hline Thuringia & 0,034 \\
\hline Metropolitan area, large city & 0,163 \\
\hline Metropolitan area, medium sized city, high population density & 0,166 \\
\hline Metropolitan area, small city, high population density & 0,049 \\
\hline Metropolitan area, medium sized city, population density above average & 0,022 \\
\hline Metropolitan area, small city, population density above average & 0,015 \\
\hline Metropolitan area, medium sized city, population density below average & 0,013 \\
\hline Metropolitan area, small city, population density below average & 0,013 \\
\hline Urban area, large city & 0,141 \\
\hline Urban area, medium sized city, high population density & 0,065 \\
\hline Urban area, small city, high population density & 0,014 \\
\hline Semi-rural, medium sized city & 0,009 \\
\hline Semi-rural, small city & 0,003 \\
\hline Rural, medium sized city & 0,065 \\
\hline Rural, small city & 0,005 \\
\hline Rural, medium sized city, low population density & 0,004 \\
\hline Rural, small city, low population density & 0,000 \\
\hline $\mathrm{N}=35,2$ & \\
\hline
\end{tabular}


Table 16: Coefficients of covariates for Table 5: residential moves

\begin{tabular}{|c|c|c|c|c|}
\hline & $\begin{array}{l}\text { Model } 1 \\
\text { residential move } \\
\text { short distance } \\
\leq 5,000 \mathrm{~m}\end{array}$ & $\begin{array}{l}\text { Model } 2 \text { (restricted) } \\
\text { residential move } \\
\text { short distance } \\
\leq 5,000 \mathrm{~m}\end{array}$ & $\begin{array}{l}\text { Model } 3 \\
\text { residential move } \\
\text { long distance } \\
>5,000 \mathrm{~m}\end{array}$ & $\begin{array}{c}\text { Model } 4 \text { (restricted) } \\
\text { residential move } \\
\text { long distance } \\
>5,000 \mathrm{~m}\end{array}$ \\
\hline principal tenant & $\begin{array}{l}-0.843 \\
(0.279)\end{array}$ & $\begin{array}{c}-0.681 \\
(0.286)\end{array}$ & $\begin{array}{l}-0.913 \\
(0.319)\end{array}$ & $\begin{array}{l}-0.719 \\
(0.319)\end{array}$ \\
\hline subtenant & $\begin{array}{l}0.0820 \\
(0.306)\end{array}$ & $\begin{array}{c}0.149 \\
(0.317)\end{array}$ & $\begin{array}{c}0.672 \\
(0.338)\end{array}$ & $\begin{array}{c}0.821 \\
(0.340)\end{array}$ \\
\hline secondary school degree & $\begin{array}{c}0.422 \\
(0.0640)\end{array}$ & $\begin{array}{c}0.399 \\
(0.0660)\end{array}$ & $\begin{array}{c}0.697 \\
(0.0880)\end{array}$ & $\begin{array}{c}0.682 \\
(0.0910)\end{array}$ \\
\hline technical college entrance qualification & $\begin{array}{c}0.582 \\
(0.104)\end{array}$ & $\begin{array}{c}0.533 \\
(0.110)\end{array}$ & $\begin{array}{c}0.977 \\
(0.131)\end{array}$ & $\begin{array}{c}0.981 \\
(0.136)\end{array}$ \\
\hline high-school diploma & $\begin{array}{c}0.369 \\
(0.0700)\end{array}$ & $\begin{array}{c}0.343 \\
(0.0740)\end{array}$ & $\begin{array}{c}1.377 \\
(0.0840)\end{array}$ & $\begin{array}{c}1.311 \\
(0.0870)\end{array}$ \\
\hline other degree & $\begin{array}{l}-0.0310 \\
(0.0870)\end{array}$ & $\begin{array}{c}-0.0170 \\
(0.0890)\end{array}$ & $\begin{array}{c}0.194 \\
(0.119)\end{array}$ & $\begin{array}{c}0.127 \\
(0.124)\end{array}$ \\
\hline no degree & $\begin{array}{c}-0.0100 \\
(0.133)\end{array}$ & $\begin{array}{c}-0.00500 \\
(0.139)\end{array}$ & $\begin{array}{l}-0.105 \\
(0.199)\end{array}$ & $\begin{array}{l}-0.131 \\
(0.205)\end{array}$ \\
\hline still in training & $\begin{array}{c}0.368 \\
(0.144)\end{array}$ & $\begin{array}{c}0.296 \\
(0.151)\end{array}$ & $\begin{array}{c}0.192 \\
(0.244)\end{array}$ & $\begin{array}{c}-0.00700 \\
(0.271)\end{array}$ \\
\hline year of construction & $\begin{array}{c}0.00200 \\
(0.00100)\end{array}$ & $\begin{array}{c}0.0140 \\
(0.00100)\end{array}$ & $\begin{array}{c}0.00400 \\
(0.00100)\end{array}$ & $\begin{array}{c}0.0160 \\
(0.00100)\end{array}$ \\
\hline flat size & $\begin{array}{l}-0.00500 \\
(0.00200)\end{array}$ & $\begin{array}{l}-0.00600 \\
(0.00200)\end{array}$ & $\begin{array}{l}-0.00400 \\
(0.00300)\end{array}$ & $\begin{array}{l}-0.00600 \\
(0.00300)\end{array}$ \\
\hline no. of rooms & $\begin{array}{l}-0.0180 \\
(0.0370)\end{array}$ & $\begin{array}{c}0.0200 \\
(0.0390)\end{array}$ & $\begin{array}{c}-0.238 \\
(0.0510)\end{array}$ & $\begin{array}{c}-0.207 \\
(0.0560)\end{array}$ \\
\hline monthly net rent & $\begin{array}{c}0.00100 \\
(0.0)\end{array}$ & $\begin{array}{c}0.00100 \\
(0.0)\end{array}$ & $\begin{array}{c}0.00100 \\
(0.0)\end{array}$ & $\begin{array}{c}0.00100 \\
(0.0)\end{array}$ \\
\hline monthly heating costs & $\begin{array}{c}-0.00200 \\
(0.001)\end{array}$ & $\begin{array}{c}-0.00200 \\
(0.001)\end{array}$ & $\begin{array}{c}-0.00100 \\
(0.001)\end{array}$ & $\begin{array}{c}0 \\
(0.001)\end{array}$ \\
\hline Metropolitan area, large city & $\begin{array}{c}0.409 \\
(0.0980)\end{array}$ & $\begin{array}{c}0.385 \\
(0.105)\end{array}$ & $\begin{array}{c}-0.0360 \\
(0.129)\end{array}$ & $\begin{array}{c}-0.0660 \\
(0.135)\end{array}$ \\
\hline Metropolitan area, medium sized city, high population density & $\begin{array}{c}0.264 \\
(0.106)\end{array}$ & $\begin{array}{c}0.247 \\
(0.112)\end{array}$ & $\begin{array}{r}-0.0290 \\
(0.141)\end{array}$ & $\begin{array}{r}-0.0800 \\
(0.145)\end{array}$ \\
\hline Metropolitan area, small city, high population density & $\begin{array}{c}0.259 \\
(0.158)\end{array}$ & $\begin{array}{c}0.225 \\
(0.163)\end{array}$ & $\begin{array}{c}0.197 \\
(0.188)\end{array}$ & $\begin{array}{c}0.163 \\
(0.194)\end{array}$ \\
\hline Metropolitan area, medium sized city, population density above average & $\begin{array}{c}0.245 \\
(0.193)\end{array}$ & $\begin{array}{l}0.0360 \\
(0.204)\end{array}$ & $\begin{array}{c}0.480 \\
(0.216)\end{array}$ & $\begin{array}{c}0.410 \\
(0.224)\end{array}$ \\
\hline Metropolitan area, small city, population density above average & $\begin{array}{l}-0.182 \\
(0.259)\end{array}$ & $\begin{array}{c}-0.341 \\
(0.271)\end{array}$ & $\begin{array}{c}0.478 \\
(0.255)\end{array}$ & $\begin{array}{c}0.363 \\
(0.262)\end{array}$ \\
\hline Metropolitan area, medium sized city, population density below average & $\begin{array}{c}-0.0540 \\
(0.267)\end{array}$ & $\begin{array}{l}-0.0460 \\
(0.273)\end{array}$ & $\begin{array}{l}0.276 \\
(0.346)\end{array}$ & $\begin{array}{l}-0.0560 \\
(0.346)\end{array}$ \\
\hline Metropolitan area, small city, population density below average & $\begin{array}{c}0.599 \\
(0.234)\end{array}$ & $\begin{array}{c}0.392 \\
(0.251)\end{array}$ & $\begin{array}{c}0.658 \\
(0.289)\end{array}$ & $\begin{array}{c}0.552 \\
(0.291)\end{array}$ \\
\hline Urban area, large city & $\begin{array}{c}0.305 \\
(0.133)\end{array}$ & $\begin{array}{c}0.267 \\
(0.138)\end{array}$ & $\begin{array}{l}-0.141 \\
(0.172)\end{array}$ & $\begin{array}{l}-0.140 \\
(0.177)\end{array}$ \\
\hline Urban area, medium sized city, high population density & $\begin{array}{c}0.672 \\
(0.142)\end{array}$ & $\begin{array}{c}0.580 \\
(0.150)\end{array}$ & $\begin{array}{c}0.209 \\
(0.182)\end{array}$ & $\begin{array}{c}0.144 \\
(0.191)\end{array}$ \\
\hline Urban area, small city, high population density & $\begin{array}{c}0.433 \\
(0.211)\end{array}$ & $\begin{array}{c}0.303 \\
(0.216)\end{array}$ & $\begin{array}{l}0.490 \\
(0.244)\end{array}$ & $\begin{array}{l}0.256 \\
(0.257)\end{array}$ \\
\hline Semi-rural, medium sized city & $\begin{array}{c}0.681 \\
(0.227)\end{array}$ & $\begin{array}{c}0.647 \\
(0.234)\end{array}$ & $\begin{array}{c}0.612 \\
(0.275)\end{array}$ & $\begin{array}{c}0.545 \\
(0.284)\end{array}$ \\
\hline Semi-rural, small city & $\begin{array}{l}-0.944 \\
(0.736)\end{array}$ & $\begin{array}{l}-0.867 \\
(0.740)\end{array}$ & $\begin{array}{c}1.077 \\
(0.368)\end{array}$ & $\begin{array}{c}0.983 \\
(0.391)\end{array}$ \\
\hline Rural, medium sized city & $\begin{array}{c}0.411 \\
(0.158)\end{array}$ & $\begin{array}{c}0.361 \\
(0.164)\end{array}$ & $\begin{array}{c}0.197 \\
(0.200)\end{array}$ & $\begin{array}{l}0.0870 \\
(0.210)\end{array}$ \\
\hline Rural, small city & $\begin{array}{c}0.230 \\
(0.344)\end{array}$ & $\begin{array}{r}-0.0510 \\
(0.395)\end{array}$ & $\begin{array}{c}0.913 \\
(0.337)\end{array}$ & $\begin{array}{c}0.854 \\
(0.348)\end{array}$ \\
\hline Rural, medium sized city, low population density & $\begin{array}{l}-1.710 \\
(1.019)\end{array}$ & $\begin{array}{l}-1.763 \\
(1.025)\end{array}$ & $\begin{array}{r}-0.0370 \\
(0.512)\end{array}$ & $\begin{array}{l}-0.415 \\
(0.561)\end{array}$ \\
\hline Rural, small city, low population density & $\begin{array}{c}2.016 \\
(0.964)\end{array}$ & $\begin{array}{c}2.102 \\
(0.982)\end{array}$ & $\begin{array}{c}1.357 \\
(1.157)\end{array}$ & $\begin{array}{c}1.421 \\
(1.070)\end{array}$ \\
\hline Constant & $\begin{array}{l}-7.222 \\
(2.329)\end{array}$ & $\begin{array}{l}-30.99 \\
(2.248)\end{array}$ & $\begin{array}{l}-10.00 \\
(2.817)\end{array}$ & $\begin{array}{l}-34.13 \\
(2.800)\end{array}$ \\
\hline $\begin{array}{l}\text { Time fixed effects } \\
\text { Federal state fixed effects }\end{array}$ & $\begin{array}{l}\text { included } \\
\text { included }\end{array}$ & $\begin{array}{l}\text { included } \\
\text { included }\end{array}$ & $\begin{array}{l}\text { included } \\
\text { included }\end{array}$ & $\begin{array}{l}\text { included } \\
\text { included }\end{array}$ \\
\hline
\end{tabular}


Figure 15: Common trends in propensity score-trimmed and -weighted treatment and control groups

a. Newly built, uncontrolled units

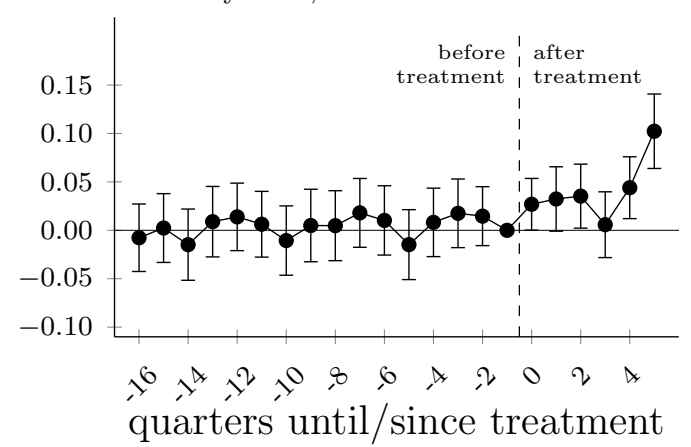

b. Rent controlled units



The figures show coefficients of the interactions of an indicator for rent cap municipalities and "event quarter" dummies (quarters relative to treatment at the local level). The regression also include postal code fixed effects and controls for housing characteristics. 


\section{OD. Demand response: additional graphs and tables}

Figure 16: Common trends in propensity score-trimmed and -weighted treatment and control groups for residential moves

(1) $\leq 5000$ meter

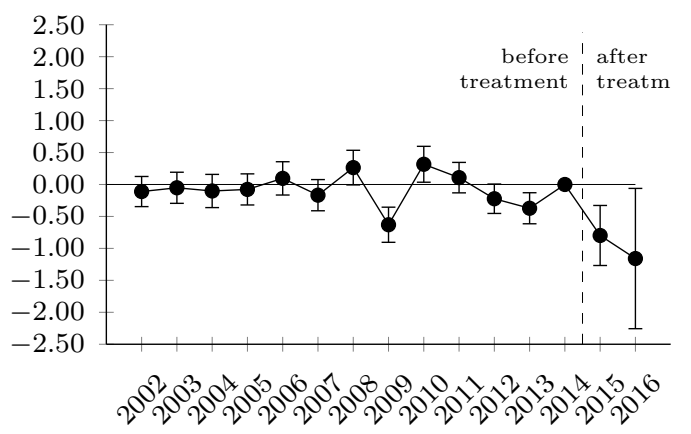

(2) $>5000$ meter

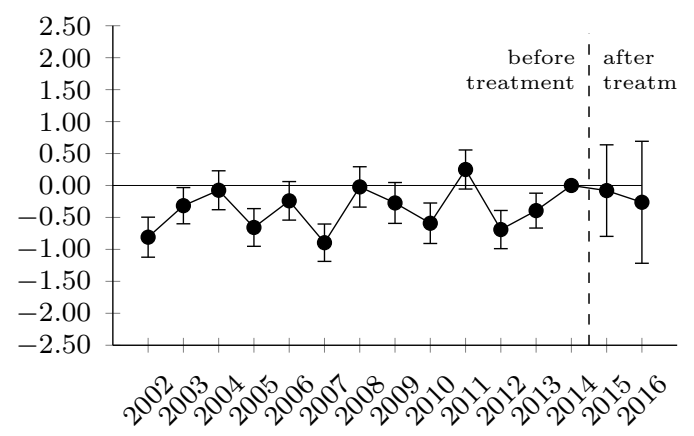

The figures show coefficients of the interactions of an indicator for rent cap municipalities and the year fixed effects from Table 5 in the main text. 


\section{OE. Supply response: additional graphs and tables}

Figure 17: Demolitions: Trends in propensity-score weighted and trimmed treatment and control groups

a) All buildings



c) Buildings w/ 3-5 units

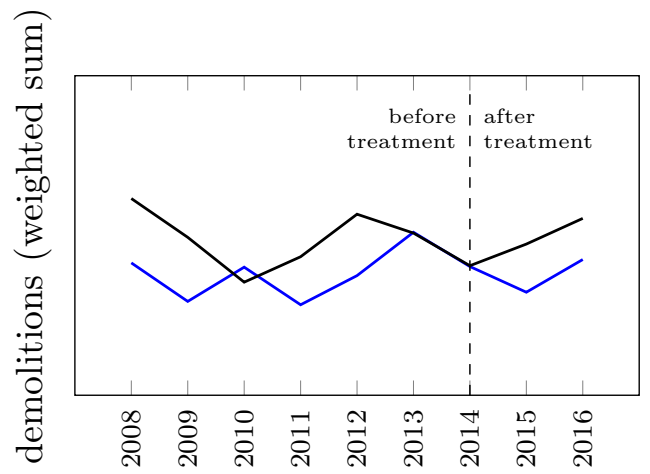

b) Buildings w/ 1-2 units



d) Buildings w/ $5+$ units




Figure 18: New housing supply: Trends in propensity-score weighted and trimmed treatment and control groups

(1) New housing units

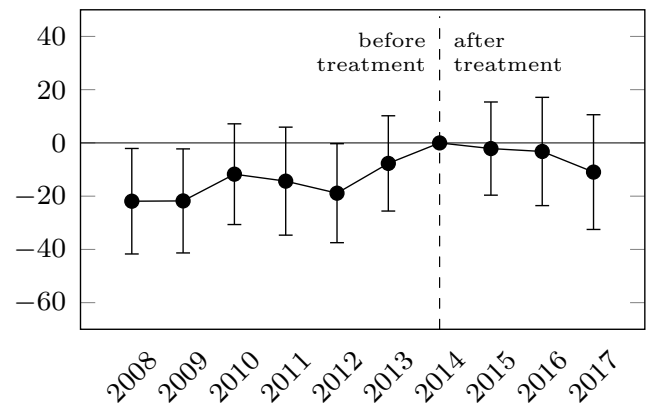

(3) Housing units per new building



(2) Conversions and changes to the stock

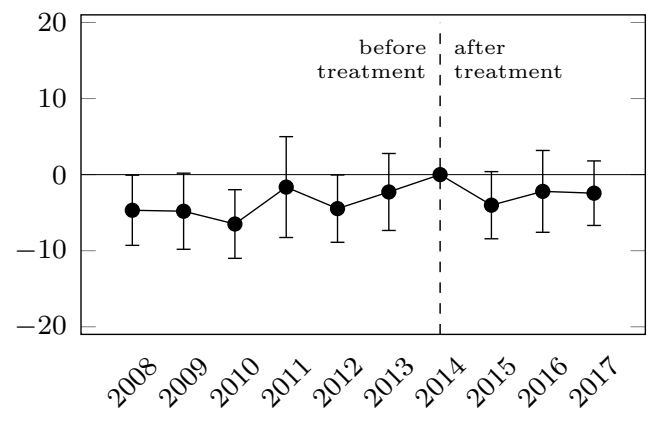

(4) Average unit size

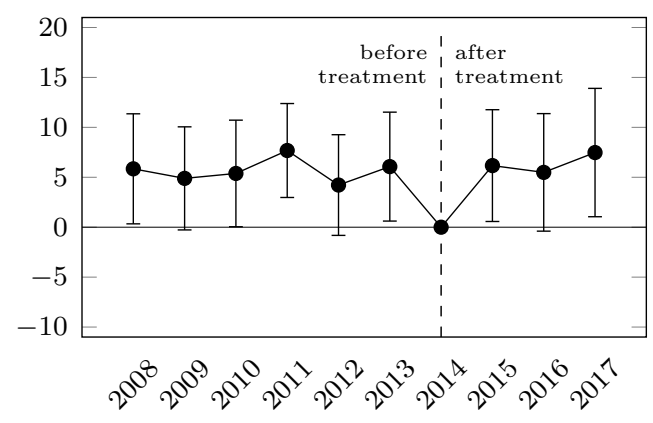


Figure 19: Housing quality: Trends in propensity-score weighted and trimmed treatment and control groups (w/o treatment effects)

(1) Refurbished



(3) Needs renovation

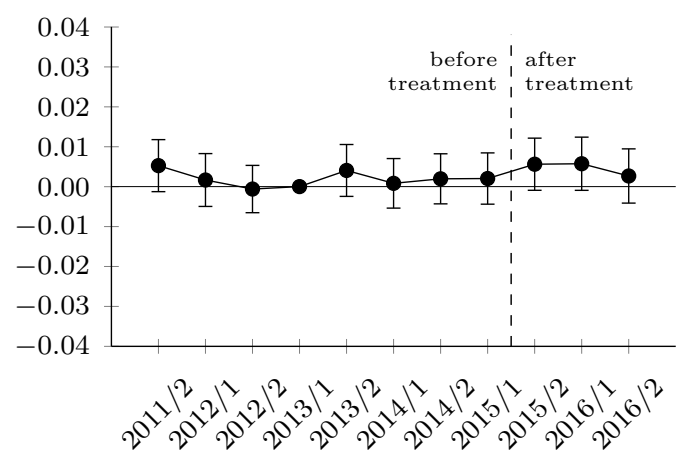

(5) high quality

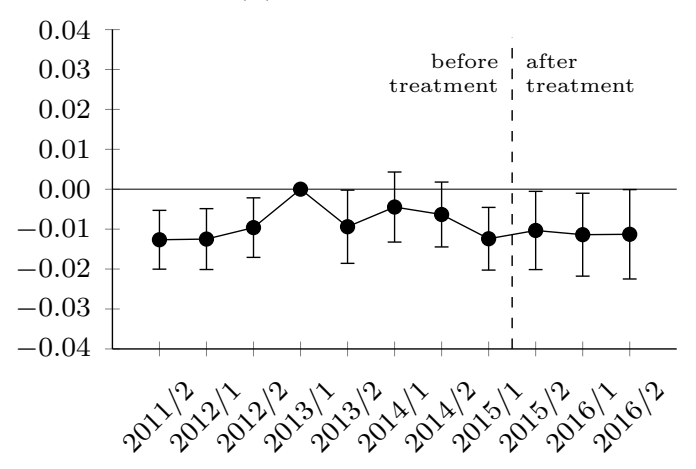

(2) Renovated

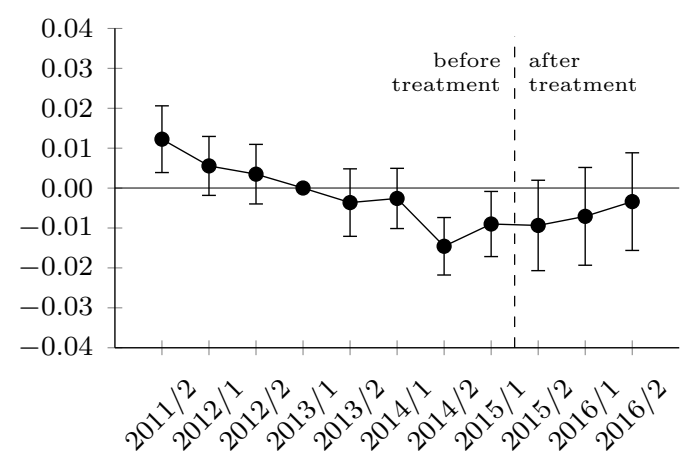

(4) fitted kitchen

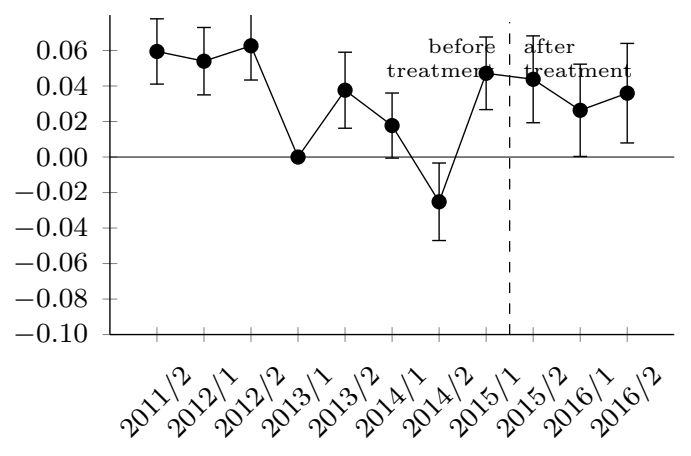

(6) low quality



